\title{
Article \\ Project Management in the Development of Dynamic Capabilities for an Open Innovation Era
}

\author{
Vânia Patrício ${ }^{1}$, Renato Lopes da Costa ${ }^{2}\left(D\right.$, Leandro Pereira ${ }^{2, *} \mathbb{D}$ and Nelson António ${ }^{2}$ \\ 1 Iscte Business School, ISCTE-University Institute of Lisbon, 1649-026 Lisboa, Portugal; \\ vania.patricio@winning.pt \\ 2 BRU—Business Research Unit, ISCTE-University Institute of Lisbon, 1649-026 Lisboa, Portugal; \\ renato_jorge_costa@iscte-iul.pt (R.L.d.C.); nelson.antonio@iscte-iul.pt (N.A.) \\ * Correspondence: leandro.pereira@iscte-iul.pt
}

check for

updates

Citation: Patrício, V.; Lopes da Costa R.; Pereira, L.; António, N. Project Management in the Development of Dynamic Capabilities for an Open Innovation Era. J. Open Innov. Technol. Mark. Complex. 2021, 7, 164. https:// doi.org/10.3390/joitmc7030164

Received: 26 May 2021

Accepted: 20 June 2021

Published: 23 June 2021

Publisher's Note: MDPI stays neutral with regard to jurisdictional claims in published maps and institutional affiliations.

Copyright: (c) 2021 by the authors. Licensee MDPI, Basel, Switzerland. This article is an open access article distributed under the terms and conditions of the Creative Commons Attribution (CC BY) license (https:// creativecommons.org/licenses/by/ $4.0 /)$.

\begin{abstract}
The aim of the research is to explain how Project Management (PM) ensures the accumulation, integration, utilization, and reconfiguration of the capabilities and knowledge acquired in projects in order to build dynamic capabilities (DCs). This study also gives insight into how PM can develop DCs through the identification and implementation of project management opportunities. The result of 22 semi-structured interviews with 22 participants from 9 companies of different industries are detailed and framed within theoretical dimensions of DCs: knowledge accumulation, integration, utilization, reconfiguration, sensing, and seizing. As a result, we present the best practices, techniques, and PM tools that allow leveraging DCs in organizations. This qualitative study contributes to a theoretical and empirical discussion about how PM transforms knowledge acquired in projects into routines and learning practices that allow organizations to develop or reshape capabilities.
\end{abstract}

Keywords: dynamic capabilities; project management; sensing; seizing; qualitative analysis; open innovation

\section{Introduction}

Through DCs, organizations reconfigure existing capabilities and develop and renew others [1]. DCs link resources with performance and influence operational capabilities [2]. They are also linked to the ability to respond to changes in the environment [2]. According to Eriksson [2], DCs consist of four core knowledge processes: accumulation, integration, utilization, and reconfiguration, which are also qualified as DCs. The same author argues that future research of these processes in more detail is needed, as well as the connection of DCs with PM [2]. Studies show the evolution of capacities in organizations [3].

This study is part of an investigation with the following phases: (1) systematic literature review about the interrelationship between PM and DCs; (2) how PM leverages DCs in organizations.

In phase 1 of the systematic literature review, 25 articles, published between 2014 and 2019, with research focused on the topic of DCs and PM, were analyzed. From the search, using DC and PM keywords, 733 articles were obtained; after refinement, an exclusion process, and detailed reading, 25 articles remained [4].

The study used the literature to analyzed the interrelationship between the two areas of study. It was found that there was a limited number of articles published in the literature with the relationship between CDs and PM.

This detailed analysis led us to conclude that one of the themes addressed by the literature is the relationship between the DCs and operational capabilities in projects [5-10]. The literature also identifies DCs found in specific projects [11-13], in specific industries, which contributed to the success of the projects or DCs that were present in certain projects [10,14-17]. 
One of the contributions of this literature review was the identification of the DCs identified in previous studies, facilitating a clear understanding of which DCs we are talking about when it comes to projects. Another contribution was the clarification of which theoretical bases were being used in these studies. We found the connection of DCs in projects to themes such as exploration and exploitation $[5,6,9,15]$, as well as seizing and sensing $[10,18,19]$.

After an in-depth literature review on DCs $[4,20]$ and on the relationship of DCs with PM [4], we found that DCs need to be revisited [15], especially their relationship with project management in a more empirical analysis about the role of project management in the development of DCs $[2,21]$.

The literature addresses existing DCs from the perspective of their contribution to a project's success and not how PM contributes to the development of DCs. In other words, the literature does not provide a theoretical and practical basis for answering what the PM should implement and use in order to leverage DCs.

It was also found that Eriksson's (2014) DC processes remain to be applied and detailed in practice in terms of PM. The question of how PM ensures the accumulation, integration, utilization, and reconfiguration of capabilities and knowledge acquired in projects in order to build DCs is not analyzed in the literature, especially the application of this theoretical basis in the framework of DCs in PM.

The second phase of the study in this paper innovates and contributes to deepening this analysis empirically.

The interconnection between change management and continuous improvement with project management was a topic addressed in a more high-level way [10], but this also needs to be further explored due to its importance and impact on the reconfiguration and utilization of new capabilities in projects and routines. Projects are implemented, but the challenge of using the knowledge acquired in routines, processes, and by people, and ensuring the transformation of capacities, is still a current challenge.

It was verified in this LR that the relation of the sensing and seizing concepts with DCs and PM still needs to be explored; namely, how PM develops DCs through projects (opportunities for change, new GP methodologies, new products/services) and how they integrate and disseminate methodologies such as agile and waterfall in order to reconfigure capabilities [10].

The demand for speed in decision-making processes [3,22], the challenges facing organizations in their internal and external responses, and the challenge of greater collaboration and communication between teams has led organizations to transform and develop new capacities and implement new methodologies, mainly agile [23]. The question arises of how project management, through seizing and sensing, captures new methodologies and implements them in organizations, thus integrating and reconfiguring project management capabilities, since organizations sometimes experience some difficulty in implementing these new methodologies.

Resource turnover in project management hinders the dissemination of knowledge between projects [10], creating a gap on how it is ensured that skills acquired between projects are replicated; this topic is still unanswered in the literature.

What is innovative about this study is the analysis of how PM can leverage DCs, through best practices, techniques, and tools that PM in organizations should develop and implement in order to build DCs through the accumulation, integration, use, and transformation of knowledge through projects. This is the new perspective and original contribution of this second phase of the study about the existing literature.

Results are also achieved by linking change management and continuous improvement with PM, as well as resource turnover in order to leverage DCs and pass on knowledge.

Another contribution relates to the analysis and articulation of these good practices and techniques with theoretical concepts such as accumulation, integration, utilization, and reconfiguring by Eriksson (2014) and sensing and seizing by Teece (2007) from the perspective of the contribution of PM to DCs. 
This paper intends to answer the overarching question: "How does project management leverage dynamic capabilities?" presenting a fundamental work to understand what it is that project management should contemplate and perform to ensure the development of DCs through projects, so that the knowledge acquired in projects is accumulated, integrated, utilized, and transformed in project management, in its routines, and in the organization. It aims to understand how this is done through the processes presented by Eriksson [2] and the concepts of sensing and seizing [10,24] applied to PM methodologies. In addition, it aims to understand what is needed for new PM methodologies, such as agile and waterfall, to be disseminated and used, and thus, reconfiguring capabilities.

Considering that qualitative methods are considered suitable for obtaining data that can capture DC and given that change is central to DC [2], the research was conducted through a qualitative study, answering the following specific research questions: (1) How does PM ensure the accumulation, integration, utilization, and reconfiguration of capabilities and knowledge acquired in the projects in order to build DCs? (2) How does PM develop DCs through the identification and implementation of project management opportunities? (3) How does the resource turnover between projects enable the accumulation, integration, utilization, and reconfiguration of knowledge?

The paper is structured in the following way: as a previous work of in-depth literature review was carried out on DCs and how they interrelate with PM, a theoretical framework on PM and its relation with DCs is presented, on the aspects to be analyzed and theoretical processes to be used. Then, the research methodology and data analysis used are explained. The discussion and findings of each research question are detailed and presented in this section. Finally, the main conclusions and limitations of this study are presented.

\section{Theoretical Framework}

\subsection{Project Management}

There are several definitions of what a project is [25]. The Project Management Institute (PMI) is considered one of the most widespread professional associations internationally [26]. The PMBOK (Project Management Body of Knowledge), is a PMI framework supporting Project Management (PM) methodology [26]. According to the PMBOK, projects are defined by being temporary and creating products, services, or outcomes that are considered unique [27] (p. 4). Projects lead to changes in organizations [27] (p. 6). Through projects, companies implement and adapt business or technology strategies; satisfy stakeholder needs; create, improve, or maintain products, processes, or services; and meet internal and external customer, regulatory, legal, or social requirements [27] (p. 8).

The concept of project management related to a waterfall approach and in a more static environment is linked to the perspective of predictability, through more detailed plans, processes, and checklists with a higher control in order to reduce changes and gain economies of scale with the size of the project [28].

Speed and technical demands have increased the number of interactions and complexity of projects [23]. The techniques used so far have become insufficient and obsolete [23,28]. The literature about PM indicates that its techniques will be complemented by approaches related to other methodologies, such as Agile, Lean, and Six Sigma, with the aim of reducing waste and allowing organizations and their teams to work in a more collaborative, communicative, and transparent way [23]. The environment has become more dynamic and there is a greater focus on adapting objectives and fast interactive releases, relinquishing some of the control [23]. These concepts are related to the term "agility," which, according to the study by Conforto et al. [29], implies the ability to change the project plan and continuously and actively involve the customer in the development process, depending on the use of agile methodologies, supposedly skeptical to the industry.

Practicing better knowledge about how to use good PM practices in organizations, as well as the best fit of these with the industry in question and the characteristics of those practicing project management, becomes essential to tackle the crisis we are witnessing [25]. Promoting training to project managers, managing their skills, developing a 
learning culture, benchmarking for project management, and continuous improvement allow improving project management in organizations [30].

\subsection{Dynamic Capabilities and Project Management}

The concept of dynamic capabilities (DC) is associated with high-level management activities [24,31].

The competitiveness of organizations depends on their ability to constantly adapt to changes and uncertainties [32]. Associated with this statement is the concept of DC, which aims to enable organizations to respond and adapt to the market [2], which represents the ability of organizations to learn [17,33], integrate, renew, reconfigure, and create new resources and capabilities, both to respond to external demands and to internal operational processes and routines $[2,5,6,9,18,31,33-38]$.

The concept of DC is related to the management's ability to identify and capture opportunities [24]. By leveraging DCs, organizations increase their capacity for competitive advantage and responsiveness to challenges, because they develop the ability to renew resources, giving them new capabilities and competencies [20].

In the literature, we can find the interconnection between DCs and PM, namely on how DCs can be applied to various PM and project domains [15]. However, this research mainly focuses on which DCs are identified in certain projects and in certain specific industries and how they impact these projects, rather than how PM develops DCs [2,5,6,8,10,11,15-18,21]. For example, Davies et al. [15] identified, through a case study, which DCs are required to deliver large, complex, and high-risk projects involving multiple stakeholders and how these were developed and implemented in the project.

Other research works looked at the relationship between DC concepts and operational capabilities [5,6,8-10,14,18]. Davies and Brady [5] addressed the concept of project capabilities, demonstrating how it supports routine and innovative projects, identifying links between project capabilities, operational level, and DC as the strategic level of the organization.

Another research line addresses the development of operational capabilities at project level and DC at portfolio level that appear as a means for TOP Management to influence organizational performance [8], along with other authors who addressed the issue of the relationship between DC and identify portfolio management as a DC [14], or how project management contributes to sustained organizational performance through the influence of dynamic capabilities [6,12].

Analyzing these authors and their research, we can identify an unexplored line of research that has to do precisely with the question of how project management leverages DC. That is, how it accumulates, acquires, integrates, develops, and transforms the capabilities and knowledge acquired in projects in organizations. The consolidation of knowledge from project to project and in the organization is still a topic to be explored [6,21]. Eriksson [2] referred to the importance of developing empirical research to further explore how project management contributes to the development of DC in organizations. Our study builds on the work of Eriksson [2], whose study found that DCs include four knowledge processes, and on the concepts of sensing and seizing developed by Teece [24].

\subsubsection{Accumulation, Integration, Utilization, and Reconfiguration of Knowledge}

Eriksson [2] identified, through his research, four fundamental processes of DC: (i) knowledge accumulation; (ii) knowledge integration; (iii) knowledge utilization; (iv) knowledge reconfiguration.

Knowledge accumulation is related to the ability of organizations to develop or renew capabilities through experience by the replication of knowledge or its renewal through external cooperation and internal learning [2], as is the case with the execution of projects [21], which are transformed into routines [16]. 
Knowledge integration happens when there is interconnection between new acquired knowledge, which is attained from external sources, with already existing knowledge through the combination of resources [2].

Knowledge utilization is the organization's ability to use acquired and integrated knowledge [2].

With knowledge reconfiguration, the organization combines new forms of knowledge through existing capabilities or transforms it into new knowledge [2]. Reconfiguration requires the changing of capabilities $[2,10]$.

As Eriksson pointed out [2] (p. 5), due to the complexity, these processes are necessarily ambiguous and overlapping.

\subsubsection{Sensing and Seizing}

In this paper, we also use Teece's [24] concepts of sensing and seizing. Sensing has to do with the market, identifying customer needs and market opportunities, developing of new knowledge, and reconfiguring capabilities [24]. Seizing is related to capturing these opportunities for the organization and implementing them $[24,39]$. Through implementation of sensing, the functions of DCs are seized and reconfigured and the operational PM resources and capabilities are changed [10]. Through sensing, improvements that need to be made to PM methodologies are identified by analyzing current and new ones [10]. Seizing allows implementing the new PM methodology and using it, changing operational PM capabilities [10].

These concepts related to DCs are interconnected with PM and appear as drivers of Open Innovation in organizations with regard to responsiveness to emerging opportunities and, consequently, to open innovation dynamics.

\section{Research Methodology}

As knowledge changes, resources and capabilities also change and develop, and the process of acquisition, accumulation, and utilization of the capabilities of a company cannot be dissociated with that of the acquisition of its knowledge [40] (p. 1028). This study adopted the following processes of DCs suggested by Eriksson [2]: the ability of the organization to accumulate, integrate, utilize, and reconfigure knowledge applied to project management, i.e., how the project management develops these DCs.

In this paper we also used Teece's [24] concepts of sensing to explain the link from DCs to PM in terms of identifying opportunities through projects and seizing to verify how the organization captures the identified opportunity. These concepts were applied to PM methodologies as suggested by Biesenthal et al. [10]: sensing to analyze current and new methodologies and seizing to implement new methodologies, joining new capabilities with current ones. The methodologies used were agile and waterfall. We identified the existing issues, gaps, and doubts in the literature review; the research questions and research objectives are shown in Table 1. 
Table 1. Literature Review Issue, Author Reference (Date), Research Question, Research Objective. Source: authors' own elaboration, 2021.

\begin{tabular}{|c|c|c|c|}
\hline & & Research Question (RQ) & Research Objective (RO) \\
\hline Literature Review Issue & Author Reference (Date) & $\begin{array}{l}\text { RQ1. How Does PM } \\
\text { Leverage DCs? }\end{array}$ & $\begin{array}{l}\text { Goal: Understand How Project } \\
\text { Management Contributes to the } \\
\text { Development of DCs }\end{array}$ \\
\hline $\begin{array}{l}\text { Several studies address that DCs are } \\
\text { built and identified in specific projects, } \\
\text { and analyzed in specific areas. Several } \\
\text { authors also mention some project } \\
\text { management tools and techniques } \\
\text { applied to specific types of projects, } \\
\text { and which projects are identified as } \\
\text { DCs or as operational capabilities that } \\
\text { build or restructure DCs. However, } \\
\text { the answer to how project } \\
\text { management can leverage DCs } \\
\text { remains unclear. }\end{array}$ & $\begin{array}{c}\text { Daniel et al. [14]; Davies } \\
\text { et al. [15]; Freitas and } \\
\text { Salerno [16] }\end{array}$ & \multirow{4}{*}{$\begin{array}{l}\text { RQ1.1. How does the PM ensure the } \\
\text { accumulation, integration, } \\
\text { utilization, and reconfiguration of } \\
\text { capabilities and knowledge } \\
\text { acquired in projects in order to } \\
\text { build DCs? }\end{array}$} & \multirow{2}{*}{$\begin{array}{l}\text { O1. Analyze how the } \\
\text { organizations guarantee the } \\
\text { development and generation of } \\
\text { new capacities through projects } \\
\text { O2. Identify which PM routines, } \\
\text { good practices, and techniques } \\
\text { enable the accumulation, } \\
\text { integration, utilization, and } \\
\text { transformation of capabilities } \\
\text { and competences }\end{array}$} \\
\hline $\begin{array}{l}\text { Conceptual models related to DC } \\
\text { processes have been developed, but } \\
\text { need to be applied empirically in } \\
\text { order to deepen how project } \\
\text { management contributes to the } \\
\text { development of DCs in organizations. }\end{array}$ & $\begin{array}{c}\text { Eriksson [2]; Medina and } \\
\text { Medina [21] }\end{array}$ & & \\
\hline $\begin{array}{l}\text { Changing management frameworks } \\
\text { emerge as a representation of a routine } \\
\text { and reconfiguration, and can support } \\
\text { the reconfiguration process of project } \\
\text { COs. Through the seizing process, the } \\
\text { organization assesses whether or not } \\
\text { to use a new PM methodology and } \\
\text { develops a change management plan } \\
\text { of how to integrate this methodology } \\
\text { with the current one. However, it does } \\
\text { not detail empirically how change } \\
\text { management should be integrated } \\
\text { and related to project management in } \\
\text { order to ensure that this process } \\
\text { occurs in a way that develops the COs, } \\
\text { especially in detail and in practice, in } \\
\text { terms of its relationship with } \\
\text { utilization and reconfiguration. }\end{array}$ & Biesenthal et al. [10] & & \multirow[t]{2}{*}{$\begin{array}{l}\text { O3. Analyze how change } \\
\text { management and continuous } \\
\text { improvement are related to } \\
\text { project management in order to } \\
\text { enhance DCs. }\end{array}$} \\
\hline $\begin{array}{l}\text { Organizations implement changes in } \\
\text { project operational resources through } \\
\text { formal processes, such as continuous } \\
\text { improvement initiatives. It would be } \\
\text { interesting to understand how these } \\
\text { continuous improvement initiatives } \\
\text { should interlink with project } \\
\text { management in order to develop DCs, } \\
\text { mainly in the use and reconfiguration } \\
\text { of DCs and in the relationship with } \\
\text { OCs (operational capabilities). }\end{array}$ & Biesenthal et al. [10] & & \\
\hline $\begin{array}{l}\text { The discussion about new and current } \\
\text { project management methodologies } \\
\text { (such as agile and waterfall) and their } \\
\text { respective relations with the creation } \\
\text { of dynamic capabilities were not } \\
\text { addressed in a detailed and practical } \\
\text { way. The relationship between sensing } \\
\text { and seizing and the new and current } \\
\text { high-level project management } \\
\text { methodologies is addressed. }\end{array}$ & Biesenthal et al. [10] & $\begin{array}{l}\text { RQ1.2. How does PM develop DCs } \\
\text { through the identification and } \\
\text { implementation of project } \\
\text { management opportunities? }\end{array}$ & $\begin{array}{l}\text { O4. Analyze how PM captures } \\
\text { opportunities for improvement in } \\
\text { terms of methodologies and } \\
\text { development of new } \\
\text { competencies in PM and how it } \\
\text { implements them. } \\
\text { O5. Analyze how the PM ensures } \\
\text { the use, integration, accumulation, } \\
\text { and transformation of } \\
\text { competencies related to new PM } \\
\text { practices and methodologies. } \\
\text { O6. Analyze whether the agile } \\
\text { and waterfall methodologies } \\
\text { develop DCs differently. }\end{array}$ \\
\hline
\end{tabular}


Table 1. Cont

\begin{tabular}{|c|c|c|c|}
\hline & & Research Question (RQ) & Research Objective (RO) \\
\hline Literature Review Issue & Author Reference (Date) & $\begin{array}{l}\text { RQ1. How Does PM } \\
\text { Leverage DCs? }\end{array}$ & $\begin{array}{l}\text { Goal: Understand How Project } \\
\text { Management Contributes to the } \\
\text { Development of DCs }\end{array}$ \\
\hline $\begin{array}{l}\text { The nature of projects leads project } \\
\text { teams to move in and out of projects, } \\
\text { even when they are not closed. This } \\
\text { hinders the dissemination and } \\
\text { codification of knowledge between } \\
\text { projects. This constant exchange } \\
\text { between resources may imply a lack } \\
\text { of loyalty within the companies, } \\
\text { because the concern is allocation from } \\
\text { project to project, reducing the } \\
\text { accumulation and integration of } \\
\text { knowledge coming from the projects, } \\
\text { and consequently, the construction of } \\
\text { DCs. It would be interesting to } \\
\text { empirically analyze this issue and } \\
\text { understand how to mitigate it. }\end{array}$ & Biesenthal et al. [10] & $\begin{array}{l}\text { RQ1.3 How does the resource } \\
\text { turnover between projects allow for } \\
\text { the accumulation, integration, } \\
\text { utilization, and reconfiguration of } \\
\text { knowledge? }\end{array}$ & $\begin{array}{l}\text { O7. Identify what factors can } \\
\text { mitigate the impact of resource } \\
\text { turnover between projects on } \\
\text { knowledge transfer, capacity } \\
\text { utilization, and codification }\end{array}$ \\
\hline
\end{tabular}

DCs are related to how organizations respond to their environment [24], the concept of which still requires clarification [15]. To explore how PM can leverage DCs, we used qualitative research [41] in order to clarify our understanding of the problem [42], allowing us to acquire information that would not have been obtained through other techniques [43], which is not solely concerned with theory generation [44]. The narrative review allows for flexibility, which makes it more suitable for inductive and qualitative research [44]. According to Yin [41], using an inductive approach allows us to work with qualitative data and use a set of methods that allow us to obtain different points of analysis about the phenomenon we are analyzing.

Considering the context of the fields of DCs and PM, the inductive and interpretive approach is suitable to analyze through experts from different companies and different industries, which have different perspectives, leading to inferences that can be generalized [42-44]. The interpretivist philosophy is considered appropriate for management research [42].

In order to support the relationship between the concepts for a better understanding of the phenomenon under study, Grounded Theory was used, which is an inductive methodology $[45,46]$.

The sample was oriented towards theory building [43]; this means that we identified interviewees and companies that could generate necessary categories [47].

Due to the complexity of the study and the fact that the current literature focuses more on specific industries [14-16], this study was applied to several companies from different industries and organizational areas related to projects and competency development. We focused on companies on a national context, namely Portugal. The sample is diverse, including companies with various characteristics to enhance the development of concepts [46]. We carried out 22 semi-structured interviews with participants from 9 companies of different industries (Figure 1), who were professionals with years of experience and responsible for areas of project management, areas with projects, and areas of skills development and members of executive committees capable of generating the categories and concepts necessary for this study. The interviewing process ended when the identification of new categories and data was exhausted (theoretical saturation) [43]. 

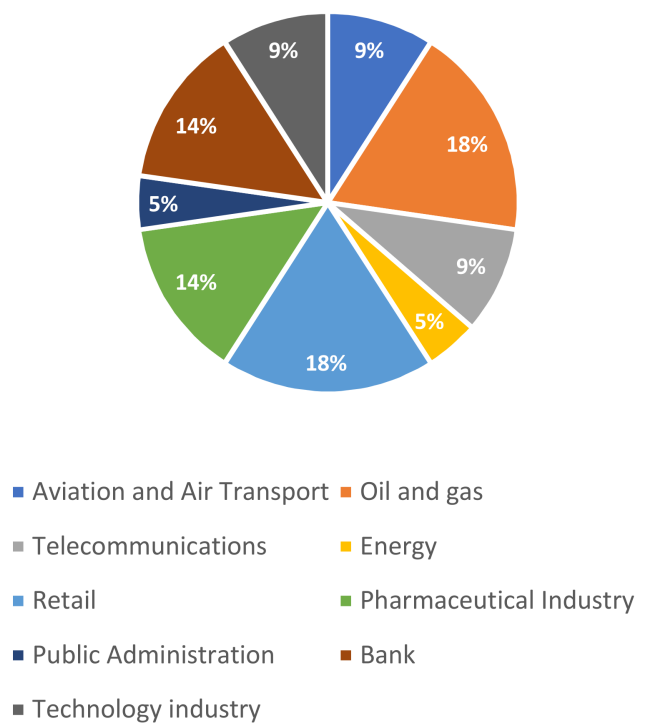

Figure 1. Sample description: industry distribution. Source: authors' own elaboration, 2021.

The interviews took between $50 \mathrm{~min}$ and $90 \mathrm{~min}$ (Table 2). The interviews were conducted in a video conference format, due to the state of the COVID-19 pandemic we currently face and the respective confinement, which made it impossible to conduct the interviews in person. They were all conducted via Microsoft Teams.

The anonymity of the interviewees and their organizations was taken into account. The interviews were recorded and transcribed in full. All interviews were conducted in Portuguese. Direct quotes were translated from Portuguese into English for presentation in this paper. With auto-recording, the interviews allowed for greater focus on what was being said [42]. No names were included, and data storage is password-protected. All participants were asked to authorize the audio-visual recording of the interviews, and $100 \%$ of them accepted.

This type of interview allowed us to seek explanations and explore the phenomenon [42], gave flexibility, which is important to clarify and deepen the understanding [44], and generated the categories [47]. Given the exploratory nature of this study, questionnaires would not be an option. Semi-structured interviews allowed us to get the interviewees' points of view, and what they consider as relevant, thus enriching the study with detailed answers [44]. As Bryman [44] mentioned, this type of interview allows the interviewee to continue to reflect on the topic, even after the interview. Two interviewees in the postinterview period referred to further interesting and related themes, which were included in their respective interviews. Where responses were longer, the interviewer summarized the response to the interviewee, and rectifications were made where necessary.

Table 2. Sample characteristics. Interviews conducted between September and October 2020. Source: authors' elaboration, 2021.

\begin{tabular}{|c|c|c|c|c|}
\hline Interviewees ID & Industry & No. of Employees & Interviewee Roles & Time (hours) \\
\hline 1 & $\begin{array}{l}\text { Aviation and Air } \\
\text { Transport }\end{array}$ & 10,000 & $\begin{array}{c}\text { Portfolio and } \\
\text { Capacity Manager }\end{array}$ & $50 \mathrm{~min}$ \\
\hline 2 & $\begin{array}{l}\text { Aviation and Air } \\
\text { Transport }\end{array}$ & 10,000 & PMO Manager & $1 \mathrm{~h}$ \\
\hline 3 & Oil and gas & 6700 & $\begin{array}{l}\text { IT and Digital } \\
\text { Project Manager }\end{array}$ & $1 \mathrm{~h}$ \\
\hline 4 & Oil and gas & 6700 & $\begin{array}{l}\text { Learning Manager } \\
\text { Manager Engineering }\end{array}$ & $1 \mathrm{~h}$ \\
\hline 5 & Oil and gas & 6700 & $\begin{array}{l}\text { and Project } \\
\text { Management Office }\end{array}$ & $50 \mathrm{~min}$ \\
\hline 6 & Telecommunications & 2400 & $\begin{array}{l}\text { Head of IT Transformation } \\
\text { Management and Projects }\end{array}$ & $1 \mathrm{~h} 20 \mathrm{~min}$ \\
\hline 7 & Energy & 11,660 & Project Manager & $1 \mathrm{~h}$ \\
\hline
\end{tabular}


Table 2. Cont.

\begin{tabular}{|c|c|c|c|c|}
\hline Interviewees ID & Industry & No. of Employees & Interviewee Roles & Time (hours) \\
\hline 8 & Retail & 4500 & IT Service Delivery Lead & $1 \mathrm{~h}$ \\
\hline 9 & Retail & 4500 & Quality Assurance & $1 \mathrm{~h}$ \\
\hline 10 & Retail & 4500 & $\begin{array}{c}\text { Program Manager and } \\
\text { PM Chapter }\end{array}$ & $1 \mathrm{~h}$ \\
\hline 11 & Bank & 6500 & IT Manager & $1 \mathrm{~h} 30 \mathrm{~min}$ \\
\hline 12 & Pharmaceutical Industry & 300 & $\begin{array}{l}\text { Supply Chain Director } \\
\text { and PMO Director }\end{array}$ & $1 \mathrm{~h} 30 \mathrm{~min}$ \\
\hline 13 & Public Administration & 300 & $\begin{array}{c}\text { PMO Director and Digital } \\
\text { Transformation } \\
\text { European Head of Project }\end{array}$ & $1 \mathrm{~h}$ \\
\hline 14 & Pharmaceutical Industry & 500 & $\begin{array}{l}\text { Management and } \\
\text { Executive Member }\end{array}$ & $1 \mathrm{~h}$ \\
\hline 15 & Bank & 850 & Agile Coach & $1 \mathrm{~h}$ \\
\hline 16 & Pharmaceutical Industry & 270 & Quality Director & $1 \mathrm{~h}$ \\
\hline 17 & Technology industry & 385,000 & $\begin{array}{l}\text { PMO Leader and PMO } \\
\text { Training Coordinator }\end{array}$ & $1 \mathrm{~h}$ \\
\hline $\begin{array}{l}18 \\
19\end{array}$ & $\begin{array}{c}\text { Technology industry } \\
\text { Retail }\end{array}$ & $\begin{array}{c}96,000 \\
8500\end{array}$ & $\begin{array}{l}\text { Program Manager } \\
\text { PMO Manager }\end{array}$ & $\begin{array}{l}1 \mathrm{~h} \\
1 \mathrm{~h}\end{array}$ \\
\hline 20 & Telecommunications & 2400 & $\begin{array}{c}\text { Head of Enterprise } \\
\text { Architecture and Projects }\end{array}$ & $1 \mathrm{~h} 15 \mathrm{~min}$ \\
\hline 21 & Bank & 400 & $\begin{array}{c}\text { CIO and } \\
\text { Executive Member }\end{array}$ & $1 \mathrm{~h}$ \\
\hline \multirow[t]{2}{*}{22} & Oil and gas & 6700 & $\begin{array}{l}\text { Global Chief Information } \\
\text { and Digital Officer }\end{array}$ & $1 \mathrm{~h}$ \\
\hline & $\begin{array}{c}\text { Online } \\
\text { interviews-total hours }\end{array}$ & & & $23 \mathrm{~h} 25 \mathrm{~min}$ \\
\hline
\end{tabular}

The checklist suggested by Bryman [44] was used to ensure that the issues from the semi-structured interviews would be considered [44] (p. 262). In order to ensure that the research instrument worked well [44], two pre-tests were conducted with two interviewees, which were not included in the results. Questions that were unclear or too long were rewritten and simplified (in questions 4 and 8, brief explanations were added to make them clearer, and question 5 was simplified). The question "How many people are involved in projects in the organization?" was removed, as it was considered to be a difficult question to answer, especially for respondents from very large companies. All rectifications identified in the pre-tests were made.

Only two interviewees requested the interview script in advance, and no other information was conveyed to the interviewees. After full transcription of the interviews, none were made available to the interviewees for correction.

The interview script was developed so that the questions were clear and easily interpreted, composing a total of 13 open questions, organized into two sections: Section 1 is a framework of how many employees the company has and the division where the interviewee is inserted; Section 2 consists of the remaining questions of the interview script, which were integrated with the research objectives and framed within the theoretical dimension used to support the research, i.e., accumulation, integration, utilization, and reconfiguration of knowledge [2] and the concepts of sensing and seizing [10,24].

The analysis was complemented with some internal documents that the interviewees provided to detail and exemplify some points, and with information from the companies' websites and social media.

\section{Data Analysis}

Data were analyzed using qualitative data analysis, where categories were coded and grouped into themes that allowed us to arrive at the model [42]. The interviews were analyzed using the qualitative data analysis software MAXQDA ${ }^{\circledR} 2020$.

Using the practices of Grounded theory, these helped greater control and insight into the work [43]. By using Grounded Theory, data collection and analysis was done simultaneously, codes and categories were constructed from the data collected, comparisons were made at each stage of analysis, theory was constructed as the data were collected 
and analyzed, and notes were written for the categories in terms of what each meant, the relationships, and related gaps $[43,45,46]$. Categories and subcategories were identified, taking into account their relationship and the general category was identified, around which the remaining categories were developed [46] (Table 3). Table 3 represents the connection between the research questions, the main category, the generic categories, the subcategories, and the theoretical dimensions framed and used.

Content analysis is objective, systematic, and transparent, where rules are applied consistently so that there is no bias [44]. The checklist presented by Bryman [44] (p. 566) and Saunders et al. [42] (p. 488) was used to ensure the quality of the process. With the full transcription of the interviews, the interview corpus was created (see Appendix A, Table A1). The categories were defined a posteriori based on the data collected in the interviews [42,45-47]. Seven categories and twelve subcategories were identified.

Table 3. Coding of the interview corpus, categorization, and theoretical dimensions. Source: authors' own elaboration, 2021.

\begin{tabular}{|c|c|c|c|c|}
\hline Research Questions & General Category & Subcategories & $\begin{array}{c}\text { Annotations/Description } \\
\text { Subcategories }\end{array}$ & Theoretical Dimensions \\
\hline $\begin{array}{l}\text { 1. How does PM } \\
\text { leverage DCs? }\end{array}$ & $\begin{array}{l}\text { The role of project } \\
\text { management in the } \\
\text { development of DCs }\end{array}$ & & & \\
\hline \multirow{7}{*}{$\begin{array}{l}\text { 1.1 How does the PM } \\
\text { ensure the accumulation, } \\
\text { integration, utilization, } \\
\text { and reconfiguration of } \\
\text { capabilities and } \\
\text { knowledge acquired in } \\
\text { projects in order to } \\
\text { build DCs? }\end{array}$} & Generic Categories & & & \\
\hline & \multirow{2}{*}{$\begin{array}{l}\text { 1.1 Development and } \\
\text { generation of new } \\
\text { capacities through projects }\end{array}$} & $\begin{array}{l}\text { 1.1.1 Transforming project } \\
\text { knowledge into routines }\end{array}$ & $\begin{array}{l}\text { 1.1.1 Transformation of } \\
\text { knowledge and learning } \\
\text { in projects into daily } \\
\text { routines and practices }\end{array}$ & 1.1.1 Accumulation \\
\hline & & $\begin{array}{l}\text { 1.1.2 Actions to address } \\
\text { the lack of } \\
\text { project knowledge }\end{array}$ & $\begin{array}{l}\text { 1.1.2 Actions to address } \\
\text { lack of project knowledge }\end{array}$ & 1.1.2 Integration \\
\hline & \multirow[b]{2}{*}{$\begin{array}{c}\text { 1.2 Project management } \\
\text { routines, best practices, } \\
\text { and techniques }\end{array}$} & $\begin{array}{l}\text { 1.2.1 PM best practices } \\
\text { that bring about } \\
\text { capacity change }\end{array}$ & $\begin{array}{l}\text { 1.2.1 Project management } \\
\text { routines, best practices, } \\
\text { techniques, competencies, } \\
\text { and processes that bring } \\
\text { about capacity } \\
\text { development, } \\
\text { dissemination, and change }\end{array}$ & $\begin{array}{l}\text { 1.2.1 Accumulation and } \\
\text { reconfiguration }\end{array}$ \\
\hline & & $\begin{array}{l}\text { 1.2.2 Facilitating and } \\
\text { blocking factors for } \\
\text { capacity development }\end{array}$ & $\begin{array}{l}\text { 1.2.2 Factors in project } \\
\text { management and in } \\
\text { projects that most facilitate } \\
\text { and those that most hinder } \\
\text { the development, } \\
\text { replication, and } \\
\text { application of new } \\
\text { competencies from project } \\
\text { to project and to } \\
\text { the organization }\end{array}$ & $\begin{array}{l}\text { 1.2.2 Accumulation, } \\
\text { integration, and utilization }\end{array}$ \\
\hline & \multirow{2}{*}{$\begin{array}{l}\text { 1.3 Relation of Change } \\
\text { Management and } \\
\text { Continuous Improvement } \\
\text { with project management }\end{array}$} & $\begin{array}{l}\text { 1.3.1 Capacity building } \\
\text { through GM in projects }\end{array}$ & $\begin{array}{l}\text { 1.3.1 Capacity } \\
\text { development through } \\
\text { change management } \\
\text { in projects }\end{array}$ & $\begin{array}{l}\text { 1.3.1 Utilization, } \\
\text { reconfiguration, } \\
\text { and seizing }\end{array}$ \\
\hline & & $\begin{array}{c}\text { 1.3.2 Capacity } \\
\text { development through CI } \\
\text { in projects }\end{array}$ & $\begin{array}{l}\text { 1.3.2 Capacity building } \\
\text { through continuous } \\
\text { improvement in projects }\end{array}$ & $\begin{array}{l}\text { 1.3.2 Utilization, } \\
\text { reconfiguration, and } \\
\text { seizing }\end{array}$ \\
\hline \multirow{2}{*}{$\begin{array}{l}\text { 1.2 How does PM develop } \\
\text { DCs by identifying and } \\
\text { implementing project } \\
\text { management } \\
\text { opportunities? }\end{array}$} & $\begin{array}{l}\text { 2.1 Capturing and } \\
\text { implementing } \\
\text { improvement } \\
\text { opportunities }\end{array}$ & $\begin{array}{l}\text { 2.1.1 Identifying and } \\
\text { implementing } \\
\text { opportunities } \\
\text { through projects }\end{array}$ & $\begin{array}{l}\text { 2.1.1 Identifying and } \\
\text { implementing } \\
\text { opportunities } \\
\text { through projects }\end{array}$ & 2.1.1 Sensing \\
\hline & $\begin{array}{l}2.2 \text { Use, integration, } \\
\text { accumulation, and } \\
\text { transformation of } \\
\text { capacities according to } \\
\text { new practices } \\
\text { and methodologies }\end{array}$ & $\begin{array}{l}\text { 2.2.1 Use and integration } \\
\text { of new PM methodologies }\end{array}$ & $\begin{array}{l}\text { 2.2.1 Use and integration } \\
\text { of new project } \\
\text { management } \\
\text { methodologies and } \\
\text { capacity development }\end{array}$ & 2.2.1 Seizing \\
\hline
\end{tabular}


Table 3. Cont.

\begin{tabular}{|c|c|c|c|c|}
\hline Research Questions & General Category & Subcategories & $\begin{array}{c}\text { Annotations/Description } \\
\text { Subcategories }\end{array}$ & Theoretical Dimensions \\
\hline & \multirow[t]{3}{*}{$\begin{array}{l}\text { 2.3 Agile and waterfall } \\
\text { methodologies and } \\
\text { capacity development }\end{array}$} & $\begin{array}{c}\text { 2.3.1 Capacity } \\
\text { development } \\
\text { differentiation between } \\
\text { methodologies }\end{array}$ & $\begin{array}{c}\text { 2.3.1 Capacity } \\
\text { development } \\
\text { differentiation between } \\
\text { waterfall and agile } \\
\text { methodologies }\end{array}$ & 2.3.1 Reconfiguration \\
\hline & & $\begin{array}{l}\text { 2.3.2 Identification of } \\
\text { capabilities developed in } \\
\text { agile and waterfall }\end{array}$ & $\begin{array}{l}\text { 2.3.2 Identification of } \\
\text { capabilities developed in } \\
\text { agile and waterfall }\end{array}$ & 2.3.2 Reconfiguration \\
\hline & & $\begin{array}{l}\text { 2.3.3 Reconfiguration of } \\
\text { capabilities through agile } \\
\text { and waterfall }\end{array}$ & $\begin{array}{l}\text { 2.3.3 Capacity } \\
\text { development and } \\
\text { reconfiguration through } \\
\text { the agile and waterfall } \\
\text { methodologies }\end{array}$ & 2.3.3 Reconfiguration \\
\hline $\begin{array}{l}1.3 \text { How does resource } \\
\text { turnover between projects } \\
\text { allow for the } \\
\text { accumulation, integration, } \\
\text { utilization, and } \\
\text { reconfiguration } \\
\text { of knowledge? }\end{array}$ & 3.1 Resource turnover & $\begin{array}{l}\text { 3.1.1 Knowledge } \\
\text { replication } \\
\text { between projects }\end{array}$ & $\begin{array}{l}\text { 3.1.1 Knowledge } \\
\text { replication between } \\
\text { projects, taking into } \\
\text { account resource turnover }\end{array}$ & 3.1.1 Accumulation \\
\hline
\end{tabular}

In line with Saunders et al. [42] (p. 490), we combined the types of processes for qualitative analysis to support the analysis: summarizing and categorizing. In summarizing, we compressed the sentences into a few words, and in categorizing, we developed the categories which allowed us to establish relationships [42]. The analytical categories and their relationships allow for a conceptual approach to the study [43]. The data were interpreted, resulting in a set of concepts that were then coded, compared, organized, merged, and renamed, giving rise to the matrix of codes and the categories and sub-categories that allowed to understand and explain the phenomenon under study $[43,45]$.

The criteria used to reinforce the quality of the research were those proposed by Lincoln and Guba [48] (and also referenced by Charmaz [43]), considered equivalent to terms used in quantitative analysis (internal and external validity and objectivity) [43], credibility, transferability, dependability, and confirmability [48].

To ensure credibility, the researcher had an intense involvement in the topic under study, minimizing distortions [48]. A cooperation with the interviewees was established in order to detect distortions. A full transcription of the interviews was made using MAXQDA ${ }^{\circledR} 2020$, where all information was included. An analysis of all the information obtained by the different authors of the study was made.

To ensure that the sample is representative of the population where generalization will be applied (transferability), the nature of the individuals and organizations that were part of the study were diverse [49].

To obtain dependability [48], all data, sentences and complete records of the entire process, full transcripts of the interviews, and use of MAXQDA ${ }^{\circledR} 2020$ to develop the database were kept, which allowed for the transparency of the data collected, including notes, relationships with literature review, and content evaluation. The remaining authors of the study acted as auditors [43]. All research steps are detailed, allowing for authenticity and accuracy [48]. Confirmability was one of the auditors' objectives [48]. For this, the same techniques were used for credibility and dependability.

The content analysis was performed by checking the top 15 words most frequently used during the interviews (Figure 2). Bigrams (Figure 3) and trigrams (Figure 4) were identified. Inappropriate words were excluded. 


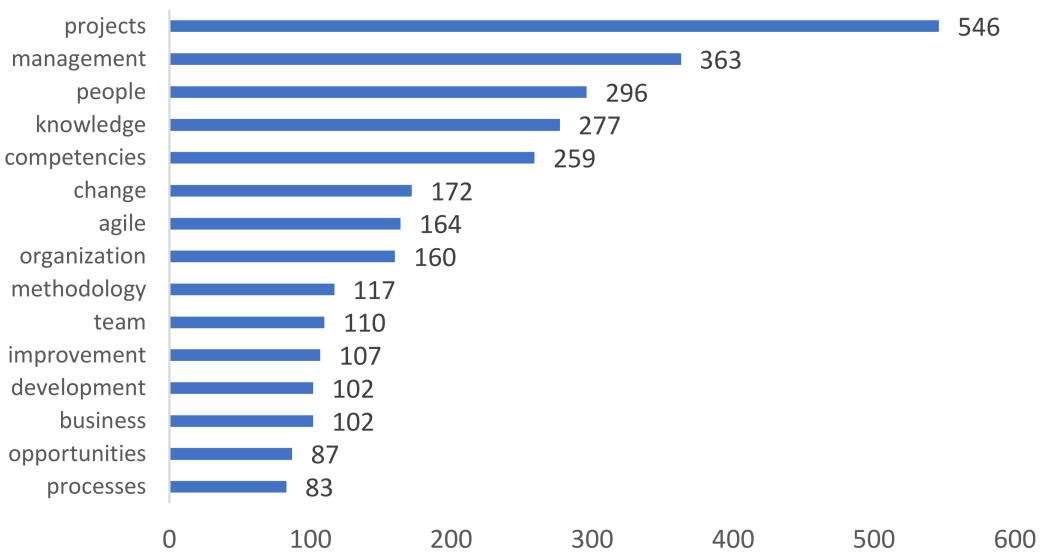

Figure 2. Top 15 of the most frequently used words. Source: authors' own elaboration, 2021.

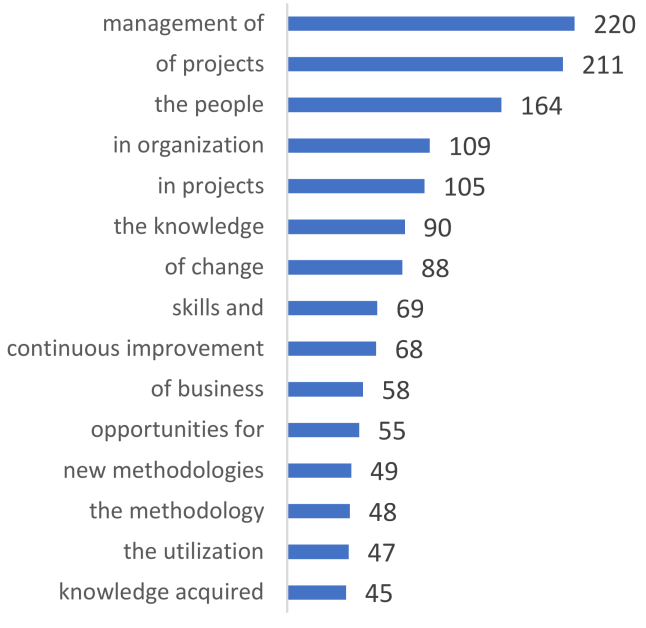

Figure 3. Top 15 of the most frequent bigrams. Source: authors' own elaboration, 2021.

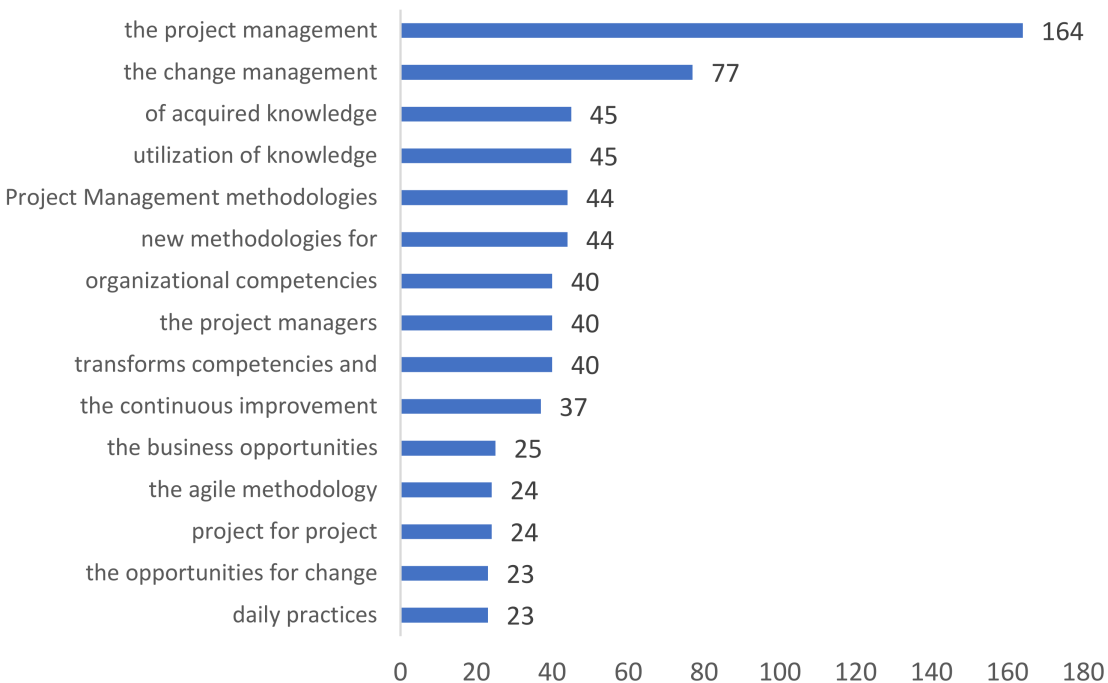

Figure 4. Top 15 of the most frequent trigrams. Source: authors' own elaboration, 2021.

There is a connection between the top 15 most frequently used words and the bi-grams and trigrams. Words and word combinations such as "projects", "management", "project management", "people", "acquired knowledge", "use of knowledge" or "competencies" 
appeared very frequently. Words and word combinations such as "change" or "change management" are often referenced in top words, bi-grams, and trigrams, which reflects the relevance given to this theme. Similarly, "methodologies" and "agile" are words that were frequently referenced by the interviewees.

\section{Discussion and Findings}

In this section, we will present and discuss the research findings.

The results aim to explain how PM leverages DCs, identifying exhaustively through best practices, PM techniques, and tools that allow accumulation, integration, utilization, and reconfiguration of knowledge through projects, as well as sensing and seizing through PM methodologies (Figure 5).

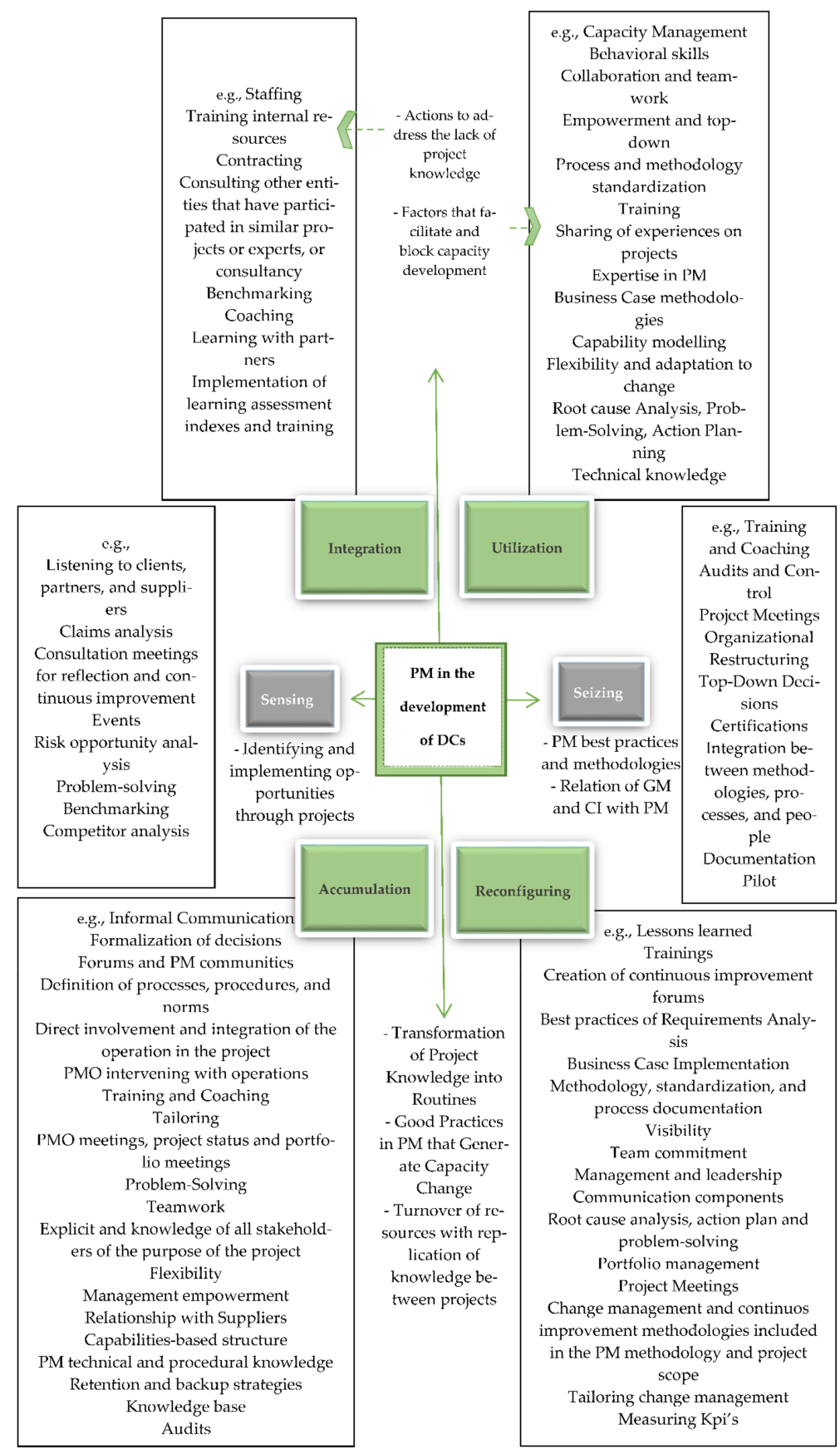

Figure 5. PM as a facilitator of DCs. Source: authors' own elaboration, 2021. 
Following the Grounded Theory method, the results of the study were compared with the existing literature $[45,46]$, which allowed increasing the quality of the theory presented [3,22] (Tables 4-6), in order to identify studies in line with the results obtained through new literature review.

Table 4. Building DCs through the accumulation, integration, utilization, and reconfiguration of capabilities and knowledge acquired in the projects. Source: authors' own elaboration, 2021.

\begin{tabular}{|c|c|c|c|c|}
\hline Generic Categories & Subcategories & $\begin{array}{c}\text { Theoretical } \\
\text { Dimensions-DCs }\end{array}$ & $\begin{array}{l}\text { PM Best Practices, Techniques, } \\
\text { and Tools That Leverage DC }\end{array}$ & $\begin{array}{l}\text { Comparison with the } \\
\text { Literature-Autor } \\
\text { Reference }\end{array}$ \\
\hline \multirow{24}{*}{$\begin{array}{l}\text { 1.1 Development and } \\
\text { generation of new } \\
\text { capacities through projects }\end{array}$} & \multirow{24}{*}{$\begin{array}{l}1.1 .1 \text { Transforming } \\
\text { project knowledge } \\
\text { into routines }\end{array}$} & \multirow{24}{*}{ Accumulation } & Informal Communication & [10] \\
\hline & & & $\begin{array}{l}\text { Analysis of recurrent problems } \\
\text { with periodic review } \\
\text { of methodologies }\end{array}$ & \\
\hline & & & Formalization of decisions taken & \\
\hline & & & Automated reporting documents & \\
\hline & & & $\begin{array}{l}\text { Forums and project management } \\
\text { communities, with thematic } \\
\text { discussion and dissemination }\end{array}$ & {$[10,16]$} \\
\hline & & & $\begin{array}{l}\text { Definition of processes, } \\
\text { procedures, and norms; norms } \\
\text { and rules for closing projects }\end{array}$ & {$[5,6,8,10,16,32]$} \\
\hline & & & $\begin{array}{l}\text { Creation of forums for project } \\
\text { initiatives and ideas }\end{array}$ & [16] \\
\hline & & & $\begin{array}{l}\text { Direct involvement and } \\
\text { integration of the operation in } \\
\text { the project }\end{array}$ & \\
\hline & & & $\begin{array}{l}\text { PMO intervening } \\
\text { with operations }\end{array}$ & \\
\hline & & & Training and Coaching & {$[5,6,10,16,38]$} \\
\hline & & & Tailoring & \\
\hline & & & Partnerships with the business & [16] \\
\hline & & & PMO newsletters & \\
\hline & & & $\begin{array}{l}\text { PMO meetings, project status, } \\
\text { and portfolio meetings }\end{array}$ & {$[10,16]$} \\
\hline & & & Flexibility & {$[2,10,15,16,50]$} \\
\hline & & & Problem-Solving & {$[2,5,15,17,19,51,52]$} \\
\hline & & & Teamwork & \\
\hline & & & $\begin{array}{l}\text { Explicit knowledge of all } \\
\text { stakeholders of the purpose of } \\
\text { the project }\end{array}$ & \\
\hline & & & Management empowerment & {$[8,38]$} \\
\hline & & & $\begin{array}{l}\text { Alliances, management and } \\
\text { relationship with suppliers }\end{array}$ & [53] \\
\hline & & & Capabilities-based structure & \\
\hline & & & $\begin{array}{l}\text { Technical and procedural } \\
\text { knowledge of the organization } \\
\text { by project management }\end{array}$ & \\
\hline & & & $\begin{array}{l}\text { Formal record of the scope of } \\
\text { projects immediately included in } \\
\text { the operation }\end{array}$ & \\
\hline & & & $\begin{array}{l}\text { Role of leadership in the } \\
\text { development and } \\
\text { transformation of knowledge }\end{array}$ & {$[6,8,38]$} \\
\hline
\end{tabular}


Table 4. Cont.

\begin{tabular}{|c|c|c|c|c|}
\hline Generic Categories & Subcategories & $\begin{array}{c}\text { Theoretical } \\
\text { Dimensions-DCs }\end{array}$ & $\begin{array}{l}\text { PM Best Practices, Techniques, } \\
\text { and Tools That Leverage DC }\end{array}$ & $\begin{array}{l}\text { Comparison with the } \\
\text { Literature-Autor } \\
\text { Reference }\end{array}$ \\
\hline & $\begin{array}{l}\text { 1.1.2 Actions to address } \\
\text { the lack of } \\
\text { project knowledge }\end{array}$ & Integration & $\begin{array}{c}\text { Staffing } \\
\text { Training internal resources } \\
\text { Contracting } \\
\text { Consulting experts or other } \\
\text { entities that have participated in } \\
\text { similar projects, or consultancy } \\
\text { Benchmarking } \\
\text { Coaching } \\
\text { Learning with partners } \\
\text { Implementation of learning } \\
\text { assessment indexes and training }\end{array}$ & $\begin{array}{c}{[16]} \\
{[16,38]} \\
{[7,16]} \\
{[2,10,17,21]}\end{array}$ \\
\hline \multirow{27}{*}{$\begin{array}{l}1.2 \text { Project management } \\
\text { routines, best practices, } \\
\text { and techniques }\end{array}$} & \multirow{16}{*}{$\begin{array}{l}\text { 1.2.1 PM best practices } \\
\text { that bring about } \\
\text { capacity change }\end{array}$} & \multirow{16}{*}{$\begin{array}{l}\text { Accumulation and } \\
\text { reconfiguration }\end{array}$} & Lessons learned & {$[10,16]$} \\
\hline & & & Creation of knowledge base & {$[12,21]$} \\
\hline & & & Trainings & {$[5,6,10,16,38]$} \\
\hline & & & Project Management Forums & {$[10,16]$} \\
\hline & & & $\begin{array}{l}\text { Customer and business } \\
\text { involvement in projects and } \\
\text { project management } \\
\text { methodology }\end{array}$ & \\
\hline & & & $\begin{array}{l}\text { Best practices of the } \\
\text { Requirements Analysis }\end{array}$ & \\
\hline & & & Business Case Implementation & [32] \\
\hline & & & $\begin{array}{l}\text { Methodology, standardization, } \\
\text { and process documentation }\end{array}$ & {$[5,6,8,10,16,32]$} \\
\hline & & & Visibility & \\
\hline & & & Team commitment & \\
\hline & & & Short-term goals & \\
\hline & & & Management and leadership & {$[6,18,38]$} \\
\hline & & & Communication components & \\
\hline & & & $\begin{array}{l}\text { Root cause analysis, action plan, } \\
\text { and problem-solving }\end{array}$ & {$[2,5,15,17,19,52]$} \\
\hline & & & Portfolio management & {$[5,6,8,10,14]$} \\
\hline & & & Project Meetings & {$[10,16]$} \\
\hline & \multirow{11}{*}{$\begin{array}{l}\text { 1.2.2 Factors that } \\
\text { facilitate and block } \\
\text { capacity development }\end{array}$} & \multirow{11}{*}{$\begin{array}{l}\text { Accumulation, } \\
\text { integration, and } \\
\text { utilization }\end{array}$} & $\begin{array}{c}\text { Capacity } \\
\text { Management-Workload and } \\
\text { execution capacity }\end{array}$ & [8] \\
\hline & & & $\begin{array}{l}\text { Behavioral, managerial, and } \\
\text { organizational skills }\end{array}$ & {$[6,18,38]$} \\
\hline & & & Collaboration and teamwork & {$[2,15,17,51,54]$} \\
\hline & & & $\begin{array}{l}\text { Empowerment and top-down } \\
\text { decisions }\end{array}$ & {$[8,30,38]$} \\
\hline & & & $\begin{array}{l}\text { Process and methodology } \\
\text { standardization }\end{array}$ & {$[5,6,8,10,16,32]$} \\
\hline & & & Training & {$[5,6,10,16,38]$} \\
\hline & & & $\begin{array}{l}\text { Sharing of experiences on } \\
\text { projects }\end{array}$ & \\
\hline & & & Project meetings & {$[10,16]$} \\
\hline & & & Expertise in Project Management & [38] \\
\hline & & & $\begin{array}{l}\text { Application of Business Case } \\
\text { methodologies }\end{array}$ & [32] \\
\hline & & & Capability modeling & \\
\hline
\end{tabular}


Table 4. Cont.

\begin{tabular}{|c|c|c|c|c|}
\hline Generic Categories & Subcategories & $\begin{array}{c}\text { Theoretical } \\
\text { Dimensions-DCs }\end{array}$ & $\begin{array}{l}\text { PM Best Practices, Techniques, } \\
\text { and Tools That Leverage DC }\end{array}$ & $\begin{array}{l}\text { Comparison with the } \\
\text { Literature-Autor } \\
\text { Reference }\end{array}$ \\
\hline & & & $\begin{array}{l}\text { Flexibility and adaptation to } \\
\text { change }\end{array}$ & {$[2,10,15,16,50]$} \\
\hline & & & $\begin{array}{c}\text { Root cause Analysis, } \\
\text { Problem-Solving, Action } \\
\text { Planning }\end{array}$ & {$[2,5,15,17,19,52]$} \\
\hline & & & Technical knowledge & [16] \\
\hline & & & Critical thinking & \\
\hline & & & $\begin{array}{l}\text { Culture of feedback and } \\
\text { reflection }\end{array}$ & \\
\hline & & & Portfolio management & \\
\hline & & & Turnover & \\
\hline \multirow{7}{*}{$\begin{array}{l}\text { 1.3 Relation of Change } \\
\text { Management and } \\
\text { Continuous Improvement } \\
\text { with project management }\end{array}$} & \multirow{6}{*}{$\begin{array}{l}\text { 1.3.1 Capacity } \\
\text { development through } \\
\mathrm{CM} \text { in projects }\end{array}$} & \multirow{6}{*}{$\begin{array}{l}\text { Utilization, } \\
\text { reconfiguration, and } \\
\text { seizing }\end{array}$} & $\begin{array}{l}\text { Change management } \\
\text { methodology included in the } \\
\text { Project Management } \\
\text { methodology and project scope }\end{array}$ & {$[10,54]$} \\
\hline & & & Tailoring change management & \\
\hline & & & Leadership through Influence & \\
\hline & & & Change Champions & {$[10,54]$} \\
\hline & & & Communication plan & \\
\hline & & & Measuring KPIs & \\
\hline & $\begin{array}{l}\text { 1.3.2 Capacity } \\
\text { development through } \\
\text { CI in projects }\end{array}$ & $\begin{array}{l}\text { Utilization, } \\
\text { reconfiguration, and } \\
\text { seizing }\end{array}$ & $\begin{array}{l}\text { Continuous improvement } \\
\text { methodology included in the } \\
\text { Project Management } \\
\text { methodology and in the scope of } \\
\text { the project } \\
\text { Methodology for implementing } \\
\text { and monitoring KPIs included in } \\
\text { the scope of the project } \\
\text { Creation of continuous } \\
\text { improvement forums } \\
\text { Supplier participation in the } \\
\text { projects and continuous } \\
\text { improvement forums } \\
\text { Critical thinking } \\
\text { Assessments }\end{array}$ & \\
\hline
\end{tabular}

Table 5. Developing DCs by identifying and implementing project management opportunities. Source: authors' own elaboration, 2021.

\begin{tabular}{|c|c|c|c|c|}
\hline Generic Categories & Subcategories & $\begin{array}{c}\text { Theoretical } \\
\text { Dimensions-DCs }\end{array}$ & $\begin{array}{l}\text { PM Best Practices, Techniques, } \\
\text { and Tools That Leverage DC }\end{array}$ & $\begin{array}{l}\text { Comparison with the } \\
\text { Literature-Autor } \\
\text { Reference (Date) }\end{array}$ \\
\hline $\begin{array}{l}\text { 2.1 Capturing and } \\
\text { implementing } \\
\text { improvement } \\
\text { opportunities }\end{array}$ & $\begin{array}{l}\text { 2.1.1 Identifying and } \\
\text { implementing } \\
\text { opportunities } \\
\text { through projects }\end{array}$ & Sensing & $\begin{array}{l}\text { Listening to clients, partners, } \\
\text { and suppliers } \\
\text { Claims analysis } \\
\text { Consultation meetings for } \\
\text { reflection and continuous } \\
\text { improvement } \\
\text { Events } \\
\text { Risk opportunity analysis } \\
\text { Problem-solving } \\
\text { Benchmarking } \\
\text { Competitor analysis }\end{array}$ & $\begin{array}{c}{[2,5,15,17,19,52]} \\
{[2,17,21]} \\
{[2,17,21]}\end{array}$ \\
\hline
\end{tabular}


Table 5. Cont.

\begin{tabular}{|c|c|c|c|c|}
\hline Generic Categories & Subcategories & $\begin{array}{c}\text { Theoretical } \\
\text { Dimensions-DCs }\end{array}$ & $\begin{array}{l}\text { PM Best Practices, Techniques, } \\
\text { and Tools That Leverage DC }\end{array}$ & $\begin{array}{l}\text { Comparison with the } \\
\text { Literature-Autor } \\
\text { Reference (Date) }\end{array}$ \\
\hline $\begin{array}{l}\text { 2.2 Utilization, integration, } \\
\text { accumulation, and } \\
\text { transformation of } \\
\text { capacities according to } \\
\text { new practices and } \\
\text { methodologies }\end{array}$ & $\begin{array}{c}\text { 2.2.1Utilization and } \\
\text { integration of new PM } \\
\text { methodologies }\end{array}$ & Seizing & $\begin{array}{c}\text { Training and Coaching } \\
\text { Audits and Control } \\
\text { Project Meetings } \\
\text { Organizational Restructuring } \\
\text { Top-Down Decisions } \\
\text { Certifications } \\
\text { Integration between } \\
\text { methodologies, processes, and } \\
\text { people } \\
\text { Documentation } \\
\text { Pilot implementation } \\
\text { Tailoring }\end{array}$ & $\begin{array}{c}{[5,6,10,16,38]} \\
{[10,16]} \\
{[8,30,38]} \\
{[5,6,8,10,16,32]} \\
{[5,6,8,10,16,32]}\end{array}$ \\
\hline \multirow{3}{*}{$\begin{array}{l}2.3 \text { Agile and waterfall } \\
\text { methodologies and } \\
\text { capacity development }\end{array}$} & $\begin{array}{c}\text { 2.3.1 Capacity } \\
\text { development } \\
\text { differentiation between } \\
\text { agile and waterfall } \\
\text { methodologies }\end{array}$ & Reconfiguration & & \\
\hline & $\begin{array}{l}2.3 .2 \text { Identification of } \\
\text { capabilities developed } \\
\text { in agile and waterfall }\end{array}$ & Reconfiguration & $\begin{array}{c}\text { Agile: } \\
\text { Process negotiation } \\
\text { Monitoring } \\
\text { Commitment } \\
\text { Adaptability } \\
\text { Responsibility } \\
\text { Team spirit } \\
\text { Knowledge sharing } \\
\text { Critical spirit } \\
\text { Agility } \\
\text { Communication } \\
\text { Waterfall: } \\
\text { Business understanding } \\
\text { Planning } \\
\text { Overview } \\
\text { Predictability }\end{array}$ & $\begin{array}{l}{[7]} \\
{[18]}\end{array}$ \\
\hline & $\begin{array}{c}\text { 2.3.3 Reconfiguration of } \\
\text { capabilities through } \\
\text { agile and waterfall }\end{array}$ & Reconfiguration & & \\
\hline
\end{tabular}

Table 6. Replication of knowledge between projects, taking into account the resource turnover. Source: authors' own elaboration, 2021.

\begin{tabular}{|c|c|c|c|c|}
\hline Generic Categories & Subcategories & $\begin{array}{c}\text { Theoretical } \\
\text { Dimensions-DCs }\end{array}$ & $\begin{array}{l}\text { PM Best Practices, } \\
\text { Techniques, and Tools } \\
\text { That Leverage DC }\end{array}$ & $\begin{array}{l}\text { Comparison with the } \\
\text { Literature-Autor } \\
\text { Reference (Date) }\end{array}$ \\
\hline \multirow{6}{*}{ 3.1 Resource turnover } & \multirow{6}{*}{$\begin{array}{l}\text { 3.1.1 Knowledge } \\
\text { replication between } \\
\text { projects }\end{array}$} & \multirow{6}{*}{ Accumulation } & $\begin{array}{l}\text { Retention and backup } \\
\text { strategies (of internal } \\
\text { employees and staffing) }\end{array}$ & \\
\hline & & & Knowledge base & {$[12,21]$} \\
\hline & & & Audits & \\
\hline & & & $\begin{array}{l}\text { Meetings for sharing and } \\
\text { passing on knowledge }\end{array}$ & \\
\hline & & & Documentation & {$[5,6,8,10,16,32]$} \\
\hline & & & Informal communication & [10] \\
\hline
\end{tabular}

Each research question will be discussed in detail in the following sections. 
5.1. RQ1: How Does Project Management Ensure the Accumulation, Integration, Utilization, and Reconfiguration of the Skills and Knowledge Acquired in Projects, in Order to Build DCs?

To answer RQ1, we verified with the interviewees how (i) the development and generation of new capabilities through projects occurs, i.e., how knowledge and capabilities are accumulated and reconfigured through projects; (ii) the mapping of routines, best practices, and techniques of project management was carried out, in order to identify how the use and integration of skills and knowledge acquired in projects is processed; and (iii) the relationship of change management and continuous improvement with the project management was identified, in order to understand how to use and reconfigure the knowledge and skills acquired in projects (Table 4).

\subsubsection{Development and Generation of New Capacities through Projects}

We considered (i) how the knowledge and learning acquired in projects is transformed into daily routines and practices, thus leveraging the accumulation of knowledge and (ii) which routines, best practices, techniques, tools, competencies, and project management processes cause development, dissemination, and change of capabilities in the organization, thus developing the accumulation and reconfiguration of capabilities absorbed in projects.

\section{Transformation of Project Knowledge into Routines}

Analyzing the results of the transformation of project knowledge into routines, we can observe that the informal communication, which exists between project teams, works very well in terms of sharing experiences, enabling learning and replication of good practices. As interviewee 16 stated: "[...] there are moments when everyone is together, they learn from each other; through informal communication that works well, they gain experience and help each other with ideas." This idea is in line with Biesenthal et al. [10], who argued that knowledge about the best way to deliver projects is transferred through informal channels-ad hoc conversations between project managers that do not follow written rules, regular meetings, or project reports (the authors highlighted this aspect by linking it more to a sensing routine in identifying new opportunities).

Several authors mentioned that informal conversations between project managers have results in project success, other than just lessons learned and formal project meetings, changing methodologies when necessary in a specific project, as well as the flexibility to solve issues that arise, as long as it is not inconsistent with organizational models and processes $[2,10,15-17,50]$. In line with these authors, one of the interviewees identified flexibility as a key element: "People's flexibility is very important in knowledge development and transformation" (Interviewee 15). Although informal communication was identified as important in knowledge accumulation, project management office (PMO) meetings, project status meetings, and portfolio meetings also emerge as important in transforming project knowledge into routines, mainly associated with meetings with more agile methodologies. As one of the interviewees explained, "doing retrospective meetings and understanding what we can improve not only in project management, but also in the IT area, in the business areas, relationship and communication within the areas, ends up being the main point of knowledge dissemination" (Interviewee 3). Project and portfolio meetings are mentioned in the literature review as important for identifying strategies, resistance, and communication, and for seeking to understand the projects [17,51] — having been pointed out as codification of knowledge into routines [16].

Eriksson [2] mentioned that problem solving is essential in DC, but it is not enough. The interviewees showed that it is necessary to analyze recurring problems with a periodic review of the methodologies, in order to facilitate the transformation of knowledge into routines, accumulating it. "When a problem gets repeated, which did not happen in this specific project but in several projects, we will discuss and analyze how we are going to improve and deal with it from now on. This serves as input to the methodology, that is, changes are included in the methodology by means of what was discussed to solve the identified and recurring problem" (Interviewee 2). This topic goes beyond the themes found 
in the literature review. In line with some authors reviewed previously $[5,15,17,19,21,38]$, problem-solving emerges as very important in PM, associated with the development of DCs. Problem-solving models provide a better understanding of problems and their solutions [52]. In the LR, we also found the relation between problem-solving in projects as a tool to explore Open Innovation in organizations [52].

The formalization of the decisions taken identified in the study emerges as an additional theme to the literature review: "If it is not written down and accessible, it does not work. People have to be involved [...] people have to see the value and management has to empower them" (Interviewee 17). Reinforcing Hermano and Martín-Cruz [8] on the importance of senior management involvement, one of the interviewees identified the importance of the active role of leadership in knowledge development and transformation: "[...] alignment of the objectives that are very different. Each director of the business unit should bring these indicators to life" (Interviewee 15).

The definition of processes, procedures, and standards identified by the interviewees reinforces what was referred to in previous literature as knowledge codification [16] and routines [53]. In it, the accumulation of knowledge and learning, when transformed into routines and practices, allows companies to develop or reformulate existing capabilities [16]. However, according to Teece [24], this is not enough for the organization's competitiveness. The definition of methodologies and their standardization was identified in the study as being important for the accumulation and transformation of knowledge from projects into routines. Methodology tailoring was also identified. In the LR, work routines, processes, and procedures in project management have been found to be related $[5,6,8,10]$. The study brings the extension to the LR on the Project Management Maturity Model, which has gained relevance: "The definition of processes and methodologies is very important [...]. A set of initiatives that ensures the components, one of them being the maturity model, has been created (the assessment of knowledge of the areas that have it and the level of maturity on it, as well as actions for us to improve)" (Interviewee 17). In order to ensure that the knowledge in the methodology is clear and understandable to all to be used correctly, one of the interviewees explained the importance of all individuals involved understanding its value: "A person does the handbook at the task level, but it is then seen together with those who do not know, in order to ensure that the knowledge is explicit and that nothing is missing [...]. We are investing in cost management. There is no process, no tool, and no education. We are building it [...] and putting the knowledge on paper is fundamental in the processes, procedures, and standards, but then what I notice is that many times, they do not even remember that there is a database that explains how to do it. People do not apply or they do not follow a PM process, or they do not use the tool in that way and they are always making up their own ways because they do not understand the value of the processes themselves, nor of the standardization" (Interviewee 12). Although in the study the project closure standards and rules were identified as an important procedure in PM for the development and generation of new capabilities through projects, one of the interviewees drew attention to "when there are problems, they are addressed post mortem and they retrieve a set of actions that they apply. The problem is that the format of lessons learned is static" (Interviewee 9). This idea is in line with what Gardiner [6] and Biesenthal et al. [10] argued - that it remains difficult to address problems in practice and to pass knowledge of the lessons learned from project to project. One of the interviewees drew attention to the importance that "lessons learned cannot be static, they must be turned into living documents" (Interviewee 9).

Freitas and Salerno [16] referenced the creation of a group discussion as encoding knowledge into routine, but this study goes further. It identifies in detail project management forums and communities, thematic discussions and dissemination, creation of project initiatives and idea forums, as well as PMO Newsletters that were considered important in transforming PM knowledge into routines by the interviewees. As one of the interviewees noted: "The various levels of explicit knowledge are very important: the tool, the standard, the education, talking about topics, having a record that they can refer back to, a recording 
[...]; increasingly more people are asking [for these tools], because increasingly more things are happening, and there is a need for theory to really turn into practice. Thus, we invested a lot in the 10,20,70 methodology: 10\% we learn through theory, $20 \%$ through observation, $70 \%$ by doing, which has to start right in education and be reinforced in our work. And we have also implemented a community of good practices; every 15 days, all the project managers of the world meet and discuss a theme (for one hour), which may be a process, a tool, a difficult experience, and with that, we become aware for the first time of that procedure or tool, although it was sent in writing" (Interviewee 12).

$\mathrm{PMO}$, project, and portfolio meetings have been identified, reinforcing the findings from the LR $[5,6,8,10,14,16]$, as well as project reports $[10,11,16]$. The note given by one interviewee goes further and reinforces the importance of reports being automated in order to increase their quality, and respect periodicity and use for transforming the knowledge of projects into routines.

The direct involvement and the integration of the operation into the project, a PMO intervening in the operations, partnerships with the business, the formal recording of the scope of projects immediately included in the operation, and the explanation and knowledge of all stakeholders of the purpose of the project were mentioned by interviewees as being fundamental. As reinforced by some of our interviewees: "if it stays within the scope of the project and it stays directly in the operation, with recognition and visibility, it helps in [the building of] knowledge" (Interviewee 14). "Partnerships with the business [are needed], so that the projects belong to the business and not to the SI. Thus, business people are [involved] in the projects, and thus, knowledge is transferred to the operation, because they are already in the project and are business people" (Interviewee 19), "[...] integrate people in the projects who then make the transition" (Interviewee 11).

Training and coaching of project managers (PMs) and team members reinforced what the LR refers to concerning the importance of these processes in formalizing knowledge and increasing DCs $[5,6,10,16,38]$. Additionally, one of the interviewees identified the importance of technical and procedural knowledge of the organization by project management (Interviewee 5).

Although alliances and partnerships have already been identified in the LR as an important example for building dynamic capabilities through the accumulation of experience and codification of knowledge absorbed through projects [16,55], the management of the relationship with suppliers is referred to in the study and associated with teamwork: "Suppliers have to be very transparent and serious in the execution of activities. There has to be a degree of mutual trust [...]. There is a good rapport and when there is no partnership and interrelationship with unexpected situations, help is more difficult [...] [a] rapport between company and supplier is fundamental for reciprocal assistance and good relationship and greater responsiveness to problems and development of mutual knowledge. [...] The most important capabilities are behavioral ones, and technical knowledge and experience in similar projects are fundamental. The complexity is such that teams have to be knowledgeable about the surroundings. [...] Quality here is key and the expertise of the supplier and the relationship we have with them. The contracting regime is what we discuss the most. The margin for failure is very small; these are installations that deal with flammable, hazardous materials and the risk is serious for the installation and for people" (Interviewee 5). Reliability capacity had previously been identified by Zhang et al. [55].

The study reveals that the capabilities-based framework is important for knowledge accumulation through projects, and one of the interviewees (Interviewee 20) argued: "It is better to change capabilities than processes. There is an interesting and safe benchmark. Before we think about time and the change that each project brings to something, one should know what that something is. [...] Decompose profit and loss as a whole into a cluster of business capabilities." 
Actions to Respond to the Lack of Project Knowledge

When there is no knowledge and capabilities within the organization to meet a challenge, the organization acquires it outside and integrates this knowledge with what already exists, combining capabilities-Eriksson's concept of integration [2]. In the study, the interviewees identified actions to respond to the lack of knowledge in projects, both at the technical and management levels. Staffing and training of internal resources were mentioned by several interviewees (14 interviewees identified staffing and 12 training), followed by coaching and hiring (five interviewees). Training and coaching are needed "in order to also ensure standardization and homogeneity," as stated by Interviewee 6 . Internal skills development, training, and staffing had emerged in the LR also as learning routines implemented by projects related to knowledge articulation [16], in line with periodic training programs [16,38]. One of the interviewees stated: "Staffing, because there is no time to go and train. With more stability one [can give better] training; nowadays, in IT, the speed does not allow for training to respond" (Interviewee 21). New hires had already been identified in previous studies by Zollo and Winter [55] as an indicator of new knowledge, and also by Zhang and Leiringer [7] and Freitas and Salerno [16], as a form of experience and learning routines implemented by projects. Capacity management and its intersection with roadmap of resource needs emerged as a theme related to staffing: "Capacity management models are important" (Interviewee 21).

Benchmarking, consulting/visiting other entities that have participated in similar projects or experts, or consulting and learning from partners were also identified as actions to take when it is necessary to seek knowledge and capabilities outside the organization. This is in line with Freitas and Salerno [16], who had identified partnerships and alliances as contributing to the creation of DCs, with the note that it works if the company has a policy to be able to take advantage of these alliances.

In accordance with the data collected, this study provides a more comprehensive view and points to the theme of implementing learning assessment indexes and trainings as an action to respond to the lack of knowledge. As interviewee 18 explained: "[...] training is mandatory and all the training they have to do goes into the evaluation of the employees. It is within the evaluation indicators themselves [that] contributes to improvement and learning. [...] the individual perspective of evaluation is associated with the index, if it contributed to learning or not. It is an evaluation index for which you either work or you fail. These is training that allow us to see who did or did not do [their task], if they fulfilled [their task] or not, or if they still need to be done. And this criterion serves as input for the performance and career evaluation model."

5.1.2. PM Routines, Best Practices, and Techniques That Enable the Accumulation, Integration, Utilization, and Transformation of Skills and Competencies

In order to identify what can leverage or hinder the development of DCs through projects, we referenced good practices that cause visible change of capabilities. To this end, a mapping was made of routines, best practices, techniques, competencies, and project management processes that cause the development, dissemination, and change of capabilities, leveraging DCs through their accumulation and transformation. Furthermore, a mapping was made of the factors in project management and in projects that most facilitate and those that most hinder the development, replication, and application of new competencies from project to project and for the organization, allowing us to understand how the accumulation, integration, and utilization of capabilities acquired in projects is achieved. In order to respond to one of the gaps identified in the LR, we also asked the interviewees how project management interrelates with change management and how it generates and transforms capabilities and ensures the use of knowledge acquired in projects. 


\section{Good Practices in PM That Generate Capacity Change}

Despite what the literature mentions about the difficulty of applying lessons learned $[6,10]$, interviewees stated that "lessons learned are in people's heads. Formally, they are not used, but when passed informally from project to project, lessons learned are passed from project manager to project manager. When transformed into workshops, podcasts, visual management, people already see them and use them. In other words, by changing the format, making them alive and not static, the dissemination and use rate increases. The same happens with the knowledge base" (Interviewee 2).

The training is identified as a good practice that causes a change in capacities. There are also project management forums "[...] for thematic discussions" (Interviewee 2), knowledge sharing sessions, "which are sessions [held] once a month where there is a speaker who talks about themes" (Interviewee 9), "talks between areas, which are sharing projects, initiatives [...] so that knowledge is disseminated" (Interviewee 6), "visits between the various geographies, with sharing of documents" (Interviewee 14).

Methodology, standardization, and process documentation were mentioned by several interviewees, associated with agile methodologies: "This methodology changed everything, agile is changing and reconfiguring skills, processes, day to day [...]" (Interviewee 10). "Agile made things more accepted by all and smoother, this is because there was business involvement, time management involvement in project management, in control, from high level the standardization became a routine, it was assimilated with standardization" (Interviewee 16). The involvement of the customer and the business in the projects and in the project management methodology is associated with the need to have the purpose of the project clear and the teams involved from the beginning: "Having people within the project that [are involved] right away in the operation of the project of the product/service [and] know the project management methodology, [that] put in the project the transmission of knowledge, but not at the end. [...] The most important thing is that people who are in operation and maintenance start to have notions of project management" (Interviewee 11). "The project manager tells them when they need the dates, and then production plans the products as if they were their products from the operation. This has, wonderfully, made things easier and smoother. They have been incorporated not as a project activity but as a day-to-day activity right into the project" (Interviewee 16).

In the study, the importance of setting short-term goals also emerges, associated with methodologies such as Kanban that lead to skills development and changes in routines according to interviewees. Associated with this theme, the requirements methodology is identified as a result in this study. As two of the interviewees referred: "If you have a greater structuring of the tasks, of the requirements, the teams are more interested and developed" (Interviewee 17). "The methodology of testing and of requirements has brought a lot of improvement. It used to be in a meeting that they made and raised the requirements and people did not remember everything. People write, commit, and have time to think and prepare. Dates [are starting to be adhered to], and hence, greater confidence and performance ensues" (Interviewee 21).

Gomes and Romão [15] analyzed how the management of benefits can help organizations obtain the dynamic capabilities needed to face market challenges. In line with this, the implementation of business cases as good PM practices that transform capabilities also arose, identified by the interviewees. As detailed by Interviewee 19: "They only do projects that really bring value to the company [ ... ]. And it is a huge mindset change, because they were not worried about the costs involved. They prioritize their value. And that changed skills and capabilities. They learned how to do a business case, evaluate the project quantitatively, and make it more factual. [This makes the process] much more rational and less based on needs [of which] you do not know [the] worth."

Portfolio management and project meetings are also repeated here as good practices, in which emphasis is given to their importance for collaboration, prioritization, and focus on what is important-in the weekly identification of risks, in tracking the activities of the previous period, in retrospective meetings in order to solve problems. The focus should 
be on the team, and on team learning, not on the individual, "continuous improvement [needs to be] included in the projects and then in the operation, always looking for a solution applied not only to projects, but to all projects and products" (Interviewee 16). The commitment of the team and with the importance of the visibility of the delivery as good practices is also related and was also identified by the interviewees. In the LR, the importance of collaboration in DCs had been identified [2,15,17,55].

Techniques such as problem-solving, root cause analysis, and action-planning are associated and identified as important for the accumulation and transformation of capabilities. As one of the interviewees detailed: "Many times there is [a presentation] at the end of the line, when what is needed is to act on the cause, on the context, to create the conditions, discipline, routine, to coach opportunity-they want to learn, but it takes so long to learn by themselves that they cannot. It is necessary to create this context, to think about what type of behavior we want to influence in order to impact results. Sometimes, we want to act at the level of behavior, sometimes at the level of numbers. And acting at the level of behavior is different from acting at the level of competencies" (Interviewee 12). Good practices related to communication are associated with multidisciplinarity, but also with agile methodologies, and "the transversality of knowledge and the capacity of people to leave their box" (Interviewee 4). Good practices-such as newsletters, team building, volunteer events, presentations on the market, exchange of experiences in projects in specific events that inform the whole company of what a given area did in terms of projects-were identified by the interviewees as facilitators of communication and even behaviors, leveraging the accumulation and reconfiguration of capabilities (Interviewees 1 , $3,4,7,9$, and 17).

The role of management and leadership appeared in this study to be associated with one-to-one meetings with the entire project team, coaching by those responsible, encouraging participation, and transversal initiatives and improvements: "It is necessary to create context, routines, quality time depending on the person's profile so that they can express desired behaviors and improve performance. Develop people, educate them. Poorly defined KPIs are often drivers of bad behavior. You have to think in terms of context, behaviors, results, to define results, but be aware of this path and work on it. In general, people want quick results. But that is not real, you do not inject knowledge and competence. You have to build competencies to have sustained behaviors that are of value and will influence outcomes. KPIs are influenced by behaviors that were developed prior" (Interviewee 12).

Top down decisions to use PM best practices and methodologies decisions associated with business, customer segmentation and knowledge, and analytical and technical capacity were also identified by the interviewees.

\section{Facilitating and Blocking Factors of Capacity Development}

Capacity management (volume of work and execution capacity) emerges in the study as a factor that can facilitate or block the development of capacity in projects. As mentioned by the interviewees: "When there is a lot of work, there is no room for continuous improvement, you will not be coaching, you do not document, you do not formalize" (Interviewee 2). "When you take and try to absorb the knowledge, be critical, the time is lacking, you do not get so deep into the skills [...] people cannot be critical, question, know why, whether or not the solution will meet the needs and propose alternative solutions" (Interviewee 6).

Interviewees identified behavioral, managerial, and organizational skills, relating these to "being able to mobilize project teams, people, and resources, looking for new solutions, always being up to date, reporting what is going to happen and what are the key skills" (Interviewee 5). Leadership development had already been mentioned in the LR $[6,16,38]$. The interviewees in this study went further and identified other components of management and leadership that facilitate or block the development of skills, such as: "people with great organizational skills, persistence, pragmatism, resistance to adversity, 
some technical knowledge, empathy, friendliness, knowing how to deal with people, knowing how to communicate, and leadership are very important skills that facilitate the application and development of project skills. People with little organization, little leadership ability, lack of persistence, absence of processes and procedures hinder the development and application of capabilities" (Interviewee 21).

The interviewees reinforced what had been mentioned in the LR about the importance of collaboration $[2,15,17,55]$ and teamwork [32]. The interviewees indicated that what facilitates most are the relationships between people, but drew attention to the fact that collaboration within teams works; however, when it comes to collaboration between areas, it becomes more difficult: "It is a competence that should not depend on how the organization is arranged. [...] Project management can be very important in contributing to collaboration between teams/between areas" (Interviewee 12). "Often, cultural issues arise [...]. It is a complex factor and demotivating when it is too much. Cultures that navigate [uncertainty] in a difficult way [ ... ] make it difficult; silos do not help either. When there is greater size, it creates a silo" (Interviewee 14).

Top management involvement had been mentioned by Hermano and Martín-Cruz [8] and Sivusuo et al. [38], in the sense that top management involvement leads to the development of project and portfolio DCs, related to decision-making capacity [55] and the definition of processes and procedures [8]. Pereira et al. [56], in a study relating knowledge management and projects in this new era of Open Innovation, found that senior managers argue that knowledge transfer in PM is a key topic. The interviewees, in addition to the importance of empowerment and sponsorship, also referred to the importance of top-down decisions to facilitate standardization and use. This theme was also raised by Fernandes et al. [30]. The operational routines and processes mentioned in the LR are related to the development of DCs [16,32]. In line with that, the interviewees noted that "what makes it most difficult is the lack of processes, of consistency between the various steps of the project, because each one does it in a different way. It causes complexity, people learn fast if they do it routinely" (Interviewee 9). They emphasized the importance of standardization and processes, of people understanding the purpose of the existence of areas in the organization responsible for ensuring methodology, that the "common information and standardization also helps the turnover that exists in staffing" (Interviewee 7). Interviewee 22 mentioned: "planning, rigor, method, training, experience, predictability, top-down in terms of compliance with processes and methodologies, sponsorship, mandatory methodology, and its correct use. If we want companies to transform, we have to define how we guarantee continuity, what we want people to learn." One of the interviewees drew attention to the role of processes: "Standard processes are there to help us do our job, to help us be productive, to make it easier to manage the team, to manage the customer; we do not have to learn formats, we just have to manage content, but processes are not rails. When there is a checklist for a meeting, the idea is not to limit those questions, it is to understand that you can change" (Interviewee 12).

Training for project managers and the whole team in PM, expertise in project management, related to permanent reinvention and sharing of experiences on projects, as well as project meetings encouraging critical participation of stakeholders were identified by the interviewees as facilitating factors if they exist in PM.

Technical knowledge was also identified in the study. Freitas and Salerno [16] had referred to industry specialization as DC.

Portfolio management is referred to by interviewees as facilitating the stimulation of integration and collaboration, in the sense that, when there are focused on common goals and cross-cutting initiatives, it helps prioritizing continuous improvement.

The interviewees identified the application of business case methodologies as a facilitating factor: "They prioritize it for its value. And that changed skills and capabilities" (Interviewee 19), in line with what was mentioned by Gomes and Romão [32]. The application of techniques such as root cause analysis, action-planning, and problem-solving also appear associated with critical thinking as facilitating factors. "But there are many 
one-to-one coaching sessions, one to ten sessions every week on root cause analysis, action planning, and cost analysis that [are done] in a mathematical way, but without a critical eye. You have to look beyond the numbers. Critical thinking is a very important capability, linked to problem-solving, root cause analysis, and action planning, which has a process and competence component that is essential. It has to be developed in companies and in education itself. Cognitive flexibility, flexibility with discipline, with standards and processes" (Interviewee 12). The flexibility and ability to adapt to change, associated with the willingness of teams and leadership to learn and the adaptation of the organization was also mentioned: "the organization will have to adapt to the new applications and not the applications to the organization. The applications no longer adapt to the team and processes to become the organization" (Interviewee 6). This factor identified by our stakeholders is in line with the topic of disciplined flexibility mentioned in previous studies $[2,10,15,16,50]$. Critical thinking, problem solving, and a culture of feedback and reflection in projects are drivers for the open innovation culture, allowing organizations to acquire knowledge and technology in the outside environment [52].

"There are rules and processes, but sometimes you need adaptability and flexibility to be able to respond" (Interviewee 15).

The existence in the organization of a culture of feedback was also identified as a facilitating factor for capacity development: "[a] culture of feedback and reflection is necessary (through day-to-day, coaching, reflection meetings)" (Interviewee 12).

Capacity modeling was also mentioned, in the sense of "saying what is going to be needed and making it known to everybody. [...] People have to know what is relevant. Shared benchmarks are the most important thing; it is about understanding what technological capabilities the organization has to have and selecting them. Carrying the knowledge into the value chain. [...] Coding/modeling with shared benchmarks in the sense that they are known by everyone. How you keep the modeling alive: selecting the right one, validating whether it is being updated [too] much or not updated enough" (Interviewee 20).

Resource turnover emerged in the study as an inhibiting factor for capacity development, related to the loss of associated knowledge.

5.1.3. Relationship of Change Management and Continuous Improvement with Project Management

Capacity Building through Change Management in Projects

According to the interviewees, in order to develop capabilities through change management (CM) in projects, the change management methodology should be included in the organization's Project Management methodology and within the scope of the project. Change management depends on the complexity and impact of the project, "it only happens in certain types of projects with some dimensions and processes already in place; when it happens, there are change management sprints where there is internal communication, there is involvement with other areas. There are approaches, strategy, small alterations where there is change, but changes that are more circumscribed to the universe of affectation or scope of communication, point by point" (Interviewee 6). "When the projects are large there is concern with change management [...]. Small projects no, but that in reality is changing the ways of doing. Small projects change the day to day [...]" (Interviewee 11). "A good streamlined change management process makes all the difference" (Interviewee 8). Associated to these points, the tailoring of change management was referred to by the interviewees as a necessary factor for the PM to generate, utilize, and reconfigure knowledge acquired in the projects.

In order to involve the areas in change management, the change champion emerges as a change agent mentioned by the interviewees, reinforcing the ideas of Biesenthal et al. [10]. These authors highlighted change management associated with the implementation of changes in project management methodologies in their study, to guide the reconfiguration process. Through a seizing process it evaluates the use of a new project management methodology and develops a change management plan of how to implement the 
new methodology into current project management capabilities [10]. These authors addressed change management associated with implementing changes in project management methodologies and operational capabilities in PM, but did not detail the interconnection of change management as a whole with dynamic capabilities in projects. This study addresses this topic.

The communication plan was mentioned as an important piece to reduce fear and ensure comfort for the teams. The KPIs and their monitoring and control were identifiedinterviewee 22 explained: "you have to have accountability, it has to be measured. Digital transformation is cultural transformation and communication. Sponsorship is fundamental, with concrete KPIs" (Interviewee 22).

Leadership through influence was considered as a factor of interconnection between $\mathrm{PM}$ and $\mathrm{CM}$, in the sense of generating, transforming, and ensuring the use of knowledge acquired in projects. One of the interviewees stated: "Another fundamental aspect is the ability to influence and this is fundamental in change management. We help to personify the why of the change, the pain of the change. The project manager with his ability to manage and influence is very important, and he must position himself as a service leader who puts his team and the organization first: server leadership and leadership through influence [...]. There is a very important parallel between project management that is able to develop capabilities for change management. Those aspects of context and driver behaviors and driver performance are fundamental. You have to first create conditions, processes, tools, educate people, so that afterwards we can expect different behaviors or get a different performance aligned with the purpose of the company" (Interviewee 12).

Change management was identified by interviewees as an area that still needs to be ensured and developed. Eight of the interviewees mentioned that they do not have change management or that there is no interconnection between change management and project management in the organization where they work, or that there is still great difficulty in change management (Interviewees 3, 4, 5, 9, 11, 12, 13, and 21). As one of the interviewees explained: "we have had a lot of difficulty and there is awareness of the need, but we still cannot act on taking knowledge management beyond the team [...]. Education [is needed] from an earlier age, considering that education in companies has to be complementary, but they have to teach us about the importance of preparation, risk, thinking beyond, continuous improvement, change management" (Interviewee 12).

\section{Capacity Building through Continuous Improvement in Projects}

The continuous improvement methodology (CI) included in the project management methodology and within the project scope was identified by the interviewees as a factor of interconnection between PM and CI in order to develop capabilities in projects and in the organization. According to some of the interviewees, nowadays, the continuous improvement is integrated into the operation and not in the projects, lacking interconnection, being an area that is still not so transversal in organizations (Interviewees 2, 13, 11, 20, 6, 21, and 14). As one of the interviewees stated "there are improvement actions focused on errors and not so much on innovation. It should be an area to be developed" (Interviewee 5). The LR mentions that organizations implement changes in project management operational resources through formal programs, such as continuous improvement initiatives [10].

The use of agile methodologies was identified by the interviewees as a way to link the two areas. "We use agile methodologies and agile methodologies give tools for that. And they ensure continuous improvement. The retrospective meetings themselves contribute to CI. [This is not the case if] you use traditional project management" (Interviewee 9).

Interviewee 16 explained how this interconnection worked well in his organization: "There are several cases where project managers develop continuous improvement activities that are transposed to the whole routine. Continuous improvement activities were inserted in the project scope itself and were replicated to the whole production and to the manufacturing and if it was not like that, we would not be able to manufacture with the competences and in the way we do today. By assembling a solution process for a certain 
problem, it was possible to solve problems in other products." The methodology for implementing and monitoring KPIs included in the scope of the project was also considered, as were assessments to "identify what is not right and opportunity for change, new services, business opportunities" (Interviewee 8).

The creation of systematization of continuous improvement forums in order to give visibility and create synergies, the creation of routines for analyzing what went well, reflections on improvements to be implemented, and opportunities were mentioned. The participation of suppliers in these forums, bringing ideas "contribute a lot because they have a different view of things, there are many different companies with many new ideas [...] you invest in continuous change" (Interviewee 7).

The development of critical thinking in the organization and in the projects was identified as a necessary factor for the development of skills: "They have to ask when they do not know, they must have critical thinking, they must question, they must know where they are going and why they are going. Design thinking, critical thinking is fundamental" (Interviewee 22).

\subsection{RQ2: How does PM Develop DCs by Identifying and Implementing Project Management Opportunities?}

Biesenthal et al. [10] studied the relationship between sensing and seizing and new project management methodologies and the currently existing ones in the organization, looking at the opportunities that existed in terms of methodologies in the market to improve current capabilities (sensing) and the evaluation of using the new PM methodology within the organization (seizing) by developing new DCs.

The results of this study demonstrate how opportunities are identified and implemented through projects and how they use and integrate these new PM methodologies, leading to leveraging DCs through current and new methodologies (Table 5).

5.2.1. Capture and Implementation of Improvement Opportunities-Identification and Implementation of Opportunities through Projects

According to the interviewees, opportunities are identified through the projects by listening to customers, as well as through partners and suppliers. Events also enable the capture of opportunities for improvement: "there is a lot of interactions outside [of the company] and [as a result, there are] accounts and reports of situations that come together with technology, methodology, and with tools that are based on and seek to explore" (Interviewee 13).

Inter-company sharing sessions, as interviewee 6 explained: "[...] go through a set of clients who have already implemented this platform, identify pains, problems, and go hand in hand with each other. The problems are identical."

Competitor analysis and benchmarking were also identified: "They will scientifically look at the market and trends and instead of receiving what the boards say they need or think they need, they will be indicating what capabilities are needed in the short, medium, and long term according to that analysis" (Interviewee 4).

These practices are drivers of open innovation in organizations, since they listen to the market, customers, and technology [52,56]. Open Innovation uses inbound and outbound knowledge to increase the speed of innovation in the organization [57].

The analysis of complaints is referred to by the interviewees as input for the implementation of opportunities through projects, as well as meetings for reflection, continuous improvement, and problem-solving: "[...] we are updating standards, detailing the standards, processes, customers' needs during the projects" (Interviewee 12).

The analysis of the opportunities of the risks identified in the projects was referred to in the study by the interviewees as something to be enhanced and developed: "They do not look at it as an opportunity, they look at opportunities as one less problem and not as an opportunity to explore. There is a lot of focus on delivering the product, using the methodology and not how to leverage" (Interviewee 11). 
Problem solving is associated with DCs [2], indicated by the interviewees of the study as a practice that allows the identification and implementation of opportunities through projects, and also appears in the literature as a driver of open innovation dynamics [52].

5.2.2. Utilization, Integration, Accumulation, and Transformation of Capacities According to New Practices and Methodologies of PM

In order to use and integrate new methodologies and develop and reconfigure capacities, interviewees considered trainings in PM methodologies on a large scale in the organization, reinforcing what had already been mentioned in the LR $[5,6,38]$, as well as coaching. The LR talks about coaching/mentoring of project managers [10]. The interviewees identified the role of agile coaches in mentoring teams.

Certifications related to PM methodologies were suggested, as well as the implementation of pilots for the use of the new methodologies, with tailoring.

Audits and control to standardize and ensure use were highlighted as important for using and integrating new methodologies. As one of the interviewees indicated: "Lack of standardization leads to non-use, standardization leads to use" (Interviewee 9). Integration between methodologies, processes, and people, ensuring that the purpose and impact of their use/non-use is understood and is aligned with strategy, was pointed out. PM emerged as having "a key role in managing dynamics and change" (Interviewee 12).

Documentation must exist, explaining the whole methodology, routines, and manuals. In the case of the agile methodology, it must explain all the formalities. The project meetings using the respective methodology were identified in the study by the interviewees.

Organizational restructuring, in order to accommodate the new methodologies and align the whole organization with the methodology, associated with top-down decisions, was identified in the study: "Change in philosophy and paradigm changed behaviors" (Interviewee 6).

This topic brings us to the topic of the role of the leadership and project team members in the understanding of open innovation, and more precisely the open business models to respond to what the market demands [58,59].

\subsubsection{Agile and Waterfall Methodologies and Capacity Development}

Another outcome of the study, looking at an existing gap in the LR, was to analyze the relationship of agile and waterfall methodologies used in PM, and their relationship with DC development, through the reconfiguration of capabilities.

Capacity Development Differentiation between Agile and Waterfall Methodologies

Concerning the theme of agile and waterfall methodology developing capabilities, of the 22 respondents, 16 (73\%) considered that the agile and waterfall methodologies develop capabilities differently (Figure 6).

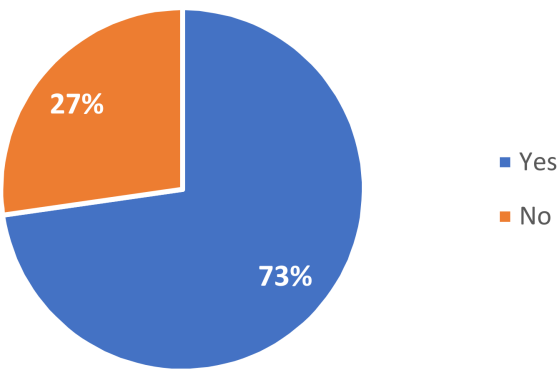

Figure 6. Capacity development differentiation between agile and waterfall methodologies. Source: authors' own elaboration, 2021.

Some of the interviewees mentioned that they tried to implement the agile methodology, but had to abandon it "because people were not prepared to decide quickly, they did not have autonomy and confidence in themselves, everything was solved in meetings with 
a lot of people. We went back to waterfall. The company was not ready" (Interviewee 21). There are organizations that try to have the two methodologies coexist: "The project management component itself was separated from the software development cycle management component and an attempt was made to have the two coexist" (Interviewee 13).

Identification of Capabilities Developed in Agile and Waterfall Methodologies

According to the interviewees, the agile methodology develops more skills at the procedural negotiation level, allows monitoring through daily meetings, facilitates transparency, and focuses people on a goal with commitment and accountability. "It promotes team spirit and knowledge sharing. They do not get locked up each doing their own thing. It makes it easier for people to ask their doubts and questions, there is more mutual help" (Interviewee 11). Furthermore, the agile methodology favors critical spirit, due to the dedication it implies, "Agile develops agility, communication, more day-to-day management" (Interviewee 10), "there is no longer communication by silos" (Interviewee 18). "Within agile, the personal relationship, communication, empathy, has to be at the highest level. The team has to function as one. There is an interconnectedness between people [who] have to function as one piece. That allows dissemination and integration of knowledge" (Interviewee 3)

According to the interviewees, the waterfall methodology develops capabilities such as business knowledge and planning, providing an overview and predictability. "In agile, we have a collection of things and we know what we deliver in each sprint, but you do not know the whole. You must have a skeleton" (Interviewee 8).

Capability Reconfiguration through the Agile and Waterfall Methodologies

In total, $41 \%$ of the interviewees noted that the agile methodology allows greater development and reconfiguration of capabilities in the organization compared to the waterfall methodology (Figure 7).

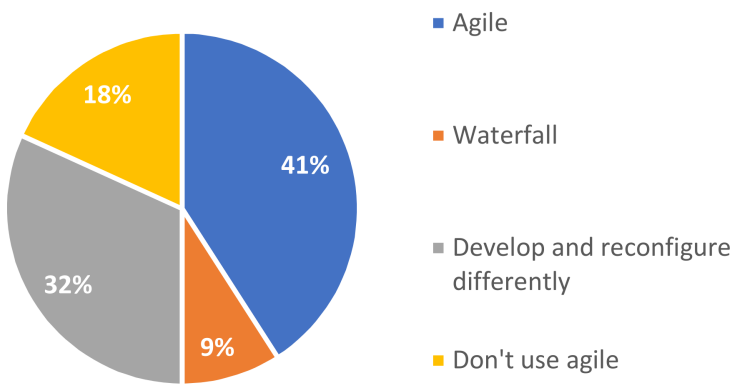

Figure 7. Reconfiguration of capabilities through the agile and waterfall methodologies. Source: authors' own elaboration, 2021.

As mentioned by Interviewee 9, "Agile [...] people have to be more multifaceted"; "agile requires more continuous accountability from the actors, requires more communication, lean and centralized" (Interviewee 21). "Agile has brought more systematization and more of these themes, whether in the problem-solving components or in customer experience and journey issues" (Interviewee 6).

In total, $32 \%$ of the interviewees mentioned that agile and waterfall methodology develop and reconfigure capabilities differently: "They do not develop one more than the other, they develop different skills" (Interviewee 2); "hybrid is what you should do and what we are doing. They have invested in transversal knowledge, such as quality management, audits, PM, and this is what transforms the resources into added value at a transversal level and we give them greater capacity to be in various different projects" (Interviewee 17); "you have to identify the best methodology that should fit. It depends on the projects. There are projects that have to be waterfall. Focus on delivery. In agile you have a faster output" (Interviewee 8); "Personal skills in agile are greater. Not of the 
whole, but of each person. [...] The documentation is a big flaw in agile. Things are not documented, it is too light in agile and that is a problem. If I have not documented, how then are we going to check things? Agile makes [use of] a more oral and unsystematized transference and that may in terms of organization make it difficult to pass competencies from the project to the operation" (Interviewee 11).

In total, $9 \%$ of interviewees stated that the waterfall methodology develops more capabilities than the agile methodology, explaining that "in the waterfall methodology, there is a capability that ends up being very well developed: contract management. Because of the scope, a lot of supplier management [is present with the waterfall methodology, which] does not happen in agile" (Interviewee 3); "[I prefer] waterfall, because it ends up being more transformational for the organizational structure of the company and mediumand long-term strategic decisions. Agile gives short-term visibility, more in tune with the processes themselves than waterfall" (Interviewee 1).

In total, $18 \%$ of the interviewees stated that they do not use agile as a methodology. According to interviewee 5, "At the industrial and engineering level, you do not apply agile methodology to large projects. [...] The design phase is too long." Interviewee 14 stated that "with the size of the projects and predictability that investors require, agile alone could not be implemented here. The change factor is constant, but at every point, they want a big waterfall traction with change management." Interviewee 20 mentioned that he uses the agile and lean methodologies.

\subsection{RQ3: How Does the Turnover of Resources between Projects Allow for the Accumulation, Integration, Utilization, and Reconfiguration of Knowledge?}

The results of the study confirm that resource turnover between projects is an inhibiting factor in developing DCs. Biesenthal et al. [10] drew attention to the fact that project managers leave projects even before they end, hindering knowledge transfer and codification. The LR indicated that the way skills and knowledge developed in each project stay in the organization and are replicated and used in other projects considering the nature of project turnover had not yet been analyzed. Table 6 shows the results of this study.

The retention and backup strategies of both internal employees and staffing were mentioned by the interviewees as necessary for knowledge to be replicated from project to project, taking into account the issue of resource turnover that is witnessed in PM. Specifically, the interviewees mentioned the importance of working conditions favorable to retention (financial, career development plan, training), the proximity of the primary structure to the most critical resources, the creation of backups of critical functions, and actions that enable knowledge transfer: "Concerning people turnover, the organization is concerned that both internal and external people feel good. The organization should bring them motivation, the work environment should be pleasant and meet the expectations of each one" (Interviewee 6). The importance of centralizing the backups in the supervisors and of them coaching, being aware of the entire operation of the area was mentioned: "On the project management side, everything remains the same, even when people leave. They [know that] the manager has well-defined backups (if the manager leaves there are already backups) and she does coaching. I never even saw it as a problem, because they have a toolkit, what I feel sorry for is the loss of personal skills" (Interviewee 16).

The creation of a knowledge base: "[...] which has trainings, papers, PM technical documents, PM glossary, thematic forums on agile. [...] this knowledge base [needs to be reviewed] in future projects - when a problem becomes habit, we adjust the methodology" (Interviewee 2). Knowledge Management areas are related to systems and tools for knowledge acquisition [60]. Audits, gate reviews, checklists, and alarm systems were mentioned by several interviewees: "One of the people in charge has a check page that is like alerts for lack of updates. [...] He has set up alarm systems to always have cards, projects, initiatives that have been waiting for feedback for more than 15 days, status updates, states of play, problems. These alarm systems are visible and available to everyone, including administration. Movement is transparency. It is a good technique to use and disseminate 
knowledge. The responsible person sees this information daily and asks the PM chapter for help to talk to the project managers to update" (Interviewee 10).

In addition to informal communication, meetings for sharing and passing on knowledge emerged as important: "they have been trying to disseminate among the project managers with meetings every 15 days, each one presents their project, lessons learned, what went well, what went wrong, to ensure that everyone works in the same way" (Interviewee 19): "There is a daily sharing of knowledge. The daily meeting focuses on the progress of the work compared with the previous day, retrospective is feedback and continuous improvement" (Interviewee 15).

Documentation was associated with the need to make documents simple and alive through sharing and dissemination in meetings: "The theme of documentation, nontraditional, from support documents, user stories, requirements, support materials to pass on skills. Nothing is done without coming around and ensuring that the capabilities, using change management, continuous integration processes, reconfigurations is achieved" (Interviewee 19); "We learned that it is not enough for someone to know how to [follow] the manual, someone who does not know about the subject has to [ ... ] understand whether everything was transmitted. The person did not transmit knowledge because they thought it was obvious" (Interviewee 12). Interviewee 20 explained how they keep the documents alive: "In every project we model the capabilities, it is mandatory. Internal employees give training, external employees suggest training. We try to make the coverage map and network, as a whole, work. We have to make sure we have active and appropriate actors in each domain. Success comes from modeling by diagrams, with business, technology, and systems capabilities and sub-capabilities, and their interrelationship. If you have a tool where you can ask for people's collaboration, [where you can] publish on an internal portal saying all the projects that have touched advertising and it shows, for example, [ ... ] what the projects have in common and quickly know what dependencies exist, and do a modeling. You realize, that way, what interrelationship they have and capabilities they need, and turn [them] into KPIs."

\section{Conclusions}

In this paper we looked at how PM can leverage DCs. The objective was to understand how project management contributes to the development of DCs and what good PM practices, techniques, and tools should be applied to develop DCs in order to enable the accumulation, integration, utilization, and reconfiguration of capabilities, using Eriksson's [2] DC processes as a theoretical basis. With it we aimed at understanding through the sensing and seizing process [24] how PM methodologies, such as waterfall and agile, can develop and reconfigure DCs [10]. In this study, we also examined how change management and continuous improvement should intertwine with PM to enable capabilities to be used and reconfigured in projects and routines. The results of the 22 interviews with several professionals from different sectors allowed us to answer three research questions: The first research question was "How does PM ensure the accumulation, integration, utilization, and reconfiguration of capabilities and knowledge acquired in projects in order to build DCs?" This was achieved by developing and generating new capabilities through projects, transforming project knowledge into routines in order to accumulate this knowledge and thus develop this DC. A total of 24 good practices, techniques, and PM tools that enable this accumulation of knowledge were identified. Eight actions were identified to respond to the absence of knowledge in projects, in order to allow the integration of knowledge to happen when the necessary capabilities do not exist. Sixteen good PM practices were identified that bring about visible change in capabilities, allowing knowledge accumulation and reconfiguration in projects. The facilitating and blocking factors of capability development were identified as being 18, with these factors-if favorable - enabling knowledge accumulation, integration, and utilization. The relationship of change management and continuous improvement with PM was the area of greatest difficulty and room for development according to the interviewees, in the sense that it still has much to improve in 
order to develop DCs, mainly the integration of CM with PM in order to ensure that the knowledge acquired in projects stays in the routines and allows the use and reconfiguration of capabilities. Six good practices, tools, and techniques were identified that allow the development of capabilities through PM in projects and another six through CM. It was verified that the agile methodology can be used as a way to leverage the continuous improvement in the PM.

The second research question "How does the PM develop DCs through the identification and implementation of project management opportunities?" was answered, and eight ways of detecting and implementing opportunities through projects, through a sensing process, were identified. For using and integrating new PM methodologies - seizing-10 good practices were identified. We found that there is differentiation in the development of capabilities between the agile and waterfall methodologies, with $41 \%$ reporting that agile develops more capabilities than waterfall, allowing a greater reconfiguration of capabilities. Conforto et al. [29] mentioned that the use of agile methodologies is supposed to be agnostic to the industry, but in the study, it was found that respondents belonging to the pharma industry use the waterfall methodology more often than agile. Some interviewed companies from the energy field, including in large and complex projects, did not apply agile.

Apart from PM, the difficulty of using documentation for knowledge and capacity development still remains a challenge, as does turnover.

The third research question "How does the resources turnover between projects allow for the accumulation, integration, utilization, and reconfiguration of knowledge?" was answered by identifying six best practices in order to understand how knowledge is replicated between projects, taking into account the turnover of resources between projects, allowing the accumulation of knowledge.

This paper contributes to a better practice and knowledge about which PM best practices, techniques, and tools organizations should be used and implemented in order to leverage DCs. It provides insight into how PM develops and integrates knowledge into processes, people, and tools. It integrates these good practices with theoretical dimensions of DCs, allowing a completeness of the study in its various dimensions, having used a sample that allows insight into various areas with interviews with very senior professionals. The study brings theoretical and practical contributions about the importance of a consolidated and studied vision so that organizations may work with a PM that contributes to the development of DCs in organizations, thus allowing an accumulation, integration, utilization, and transformation of capabilities, integrating them in routines, and allowing their day-to-day continuity, enhancing opportunities related to PM. This study helped went beyond this evolutionary economy with complexity that we are witnessing; it also helped to understand that promoting DCs through these PM practices and techniques allows the accumulation, integration, utilization, and transformation of knowledge, through both sensing and seizing, which are drivers of open innovation dynamics [59].

\section{Limitations and Future Lines of Research}

Like all studies, this research has limitations. Only a small number of interviews were conducted, taking into account the size of some of the interviewed companies, as well as the number of companies in Portugal (according to Statistics Portugal's report of companies in Portugal, in 2019, there were 1,318,330 non-financial companies), and the fact that the study was only conducted in Portugal (although there were companies with international operations in the sample). The sample can be justified by its theoretical saturation, since the marginal utility of the data collected was reached after the number of interviews conducted. Furthermore, there was no expectation of obtaining important new information in more and new interviews [42].

Future studies can be done in other contexts, besides Portugal. Future studies can work on quantitative analysis, taking into account the results of this study. A future line of research could be the deepening of the theme of change management in projects with DCs. 
In the LR, in some articles related to the subject of this study, the term Open Innovation appears related to knowledge of the organization [56,60], and has been the focus of several investigations [61]. The projects and the knowledge they generate are related to the development of open innovation [52]. Pereira et al. [56,60] focused on the importance of external knowledge absorptive capacity being dependent on internal knowledge absorptive capacity. Looking at these terms, relating Open Innovation with knowledge and projects, we identify a knowledge gap in the relationship between projects and their capacity to develop Open Innovation, through sensing, seizing, accumulation, and integration. Future studies on the relationship and the role of projects in the development of Open Innovation, associated with the development of DCs, mainly concerning processes related to sensing, seizing, accumulation, and integration of knowledge, are, therefore, suggested. The relationship of Open Innovation with knowledge transformation is also referred to in the LR $[56,60]$, being pointed out as another future research path to be detailed. The tools and techniques needed to increase the quality and speed that Open Innovation requires, such as Problem-Solving, among others [52], intersect with techniques and tools also used in projects [52]. Research into which tools and techniques enable an Open Innovation dynamic through projects and DCs would be an important empirical study in these areas.

Sustainability is a current challenge, especially in the energy sector, which requires companies to innovate [62]. Another current challenge of this industry, for example, is the innovation of processes to increase efficiency related to this issue of sustainability and cost reduction [63]. This scenario imposes a new requirement in the development of DCs so that organizations can respond to these current challenges, adding the complexity that these are industries that are very dependent on suppliers, with complex and high-risk projects. The challenges in terms of sustainability, cost reduction, and efficiency with DCs and the nature of the projects that these industries have been developing has made empirical studies essential in order to help organizations respond to the various internal and external demands.

Author Contributions: Conceptualization, V.P.; methodology, V.P.; validation, V.P., R.L.d.C., L.P., and N.A.; formal analysis, V.P.; investigation, V.P.; resources, V.P.; data curation, V.P.; writingoriginal draft preparation, V.P.; writing-review and editing, V.P.; visualization, V.P.; supervision, V.P., R.L.d.C., L.P., and N.A.; project administration, V.P.; funding acquisition, not applicable. All authors have read and agreed to the published version of the manuscript.

Funding: This research received no external funding.

Institutional Review Board Statement: Not applicable.

Informed Consent Statement: Informed consent was obtained from all subjects involved in the study.

Data Availability Statement: All data were anonymized.

Conflicts of Interest: The authors declare no conflict of interest.

\section{Appendix A}

Table A1. Interview corpus. Source: authors' own elaboration, 2021.

\begin{tabular}{|c|c|c|c|}
\hline $\begin{array}{c}\text { Research Question } \\
\text { (RQ) }\end{array}$ & $\begin{array}{c}\text { Research Objective } \\
\text { (RO) }\end{array}$ & $\begin{array}{c}\text { Interviewees' } \\
\text { IQ) }\end{array}$ & $\begin{array}{l}\text { Theoretical Dimensions } \\
\text { (TD) }\end{array}$ \\
\hline $\begin{array}{c}\text { 1. How does PM leverage } \\
\text { DCs? }\end{array}$ & $\begin{array}{l}\text { Understand how project } \\
\text { management contributes to } \\
\text { the development of DCs }\end{array}$ & & \\
\hline
\end{tabular}


Table A1. Cont.

\begin{tabular}{|c|c|c|c|}
\hline $\begin{array}{l}\text { Research Question } \\
\text { (RQ) }\end{array}$ & $\begin{array}{l}\text { Research Objective } \\
\text { (RO) }\end{array}$ & $\begin{array}{c}\text { Interviewees' Questions } \\
\text { (IQ) }\end{array}$ & $\begin{array}{l}\text { Theoretical Dimensions } \\
\text { (TD) }\end{array}$ \\
\hline \multirow{6}{*}{$\begin{array}{l}\text { 1.1 How does the PM ensure } \\
\text { the accumulation, integration, } \\
\text { use, and reconfiguration of } \\
\text { capabilities and knowledge } \\
\text { acquired in projects in order } \\
\text { to build DCs? }\end{array}$} & \multirow[t]{2}{*}{$\begin{array}{l}\text { O1. Analyze how } \\
\text { organizations ensure the } \\
\text { development and generation } \\
\text { of new capacities } \\
\text { through projects }\end{array}$} & $\begin{array}{l}\text { 2. How does project } \\
\text { management transform the } \\
\text { knowledge and learning } \\
\text { gained from projects (during } \\
\text { execution and } \\
\text { post-implementation) into } \\
\text { day-to-day routines } \\
\text { and practices? }\end{array}$ & 2. Accumulation \\
\hline & & $\begin{array}{l}\text { 3. When the necessary } \\
\text { knowledge and skills to } \\
\text { execute a project are lacking, } \\
\text { what do they do? }\end{array}$ & 3 Integration \\
\hline & \multirow{2}{*}{$\begin{array}{l}\text { O2. Identify which PM } \\
\text { routines, best practices, and } \\
\text { techniques enable the } \\
\text { accumulation, integration, use, } \\
\text { and transformation of skills } \\
\text { and competencies. }\end{array}$} & $\begin{array}{l}\text { 4. What routines, best } \\
\text { practices, techniques, } \\
\text { competencies, and project } \\
\text { management processes have } \\
\text { caused development, } \\
\text { dissemination, and visible } \\
\text { change of capacities in } \\
\text { the organization? }\end{array}$ & $\begin{array}{l}\text { 4. Accumulation and } \\
\text { reconfiguration }\end{array}$ \\
\hline & & $\begin{array}{l}\text { 5. What are the factors in } \\
\text { project management and in } \\
\text { projects that most facilitate } \\
\text { and those that most hinder the } \\
\text { development, replication, and } \\
\text { application of new } \\
\text { competencies from project to } \\
\text { project and to } \\
\text { the organization? }\end{array}$ & $\begin{array}{l}\text { 5. Accumulation, integration, } \\
\text { and utilization }\end{array}$ \\
\hline & \multirow[t]{2}{*}{$\begin{array}{l}\text { O3. Analyze how change } \\
\text { management and continuous } \\
\text { improvement are related to } \\
\text { project management in order } \\
\text { to enhance DCs. }\end{array}$} & $\begin{array}{l}\text { 6. How does project } \\
\text { management interrelate with } \\
\text { change management and how } \\
\text { does it, thereby, generate and } \\
\text { transform competencies and } \\
\text { ensure the use of knowledge } \\
\text { acquired in projects? }\end{array}$ & $\begin{array}{l}\text { 6. Utilization, reconfiguration, } \\
\text { and seizing }\end{array}$ \\
\hline & & $\begin{array}{l}\text { 7. How does project } \\
\text { management interrelate with } \\
\text { continuous improvement and } \\
\text { how does it generate and } \\
\text { transform competencies and } \\
\text { ensure the use of knowledge } \\
\text { acquired in projects? }\end{array}$ & $\begin{array}{l}\text { 7. Utilization, reconfiguration, } \\
\text { and seizing }\end{array}$ \\
\hline $\begin{array}{l}\text { 1.2 How does GP develop } \\
\text { DCs by identifying and } \\
\text { implementing project } \\
\text { management opportunities? }\end{array}$ & $\begin{array}{l}\text { O4. Analyze how PM } \\
\text { captures opportunities for } \\
\text { improvement in terms of } \\
\text { methodologies and } \\
\text { development of new } \\
\text { competencies in PM and how } \\
\text { it implements them }\end{array}$ & $\begin{array}{l}\text { 8. How do you identify } \\
\text { opportunities through projects } \\
\text { (opportunities for change, for } \\
\text { new PM methodologies, for } \\
\text { new products/services, etc.)? }\end{array}$ & 8. Sensing \\
\hline
\end{tabular}


Table A1. Cont.

\begin{tabular}{|c|c|c|c|}
\hline $\begin{array}{l}\text { Research Question } \\
\text { (RQ) }\end{array}$ & $\begin{array}{c}\text { Research Objective } \\
\text { (RO) }\end{array}$ & $\begin{array}{c}\text { Interviewees' Questions } \\
\text { (IQ) }\end{array}$ & $\begin{array}{l}\text { Theoretical Dimensions } \\
\text { (TD) }\end{array}$ \\
\hline & $\begin{array}{l}\text { O5. Analyze how PM ensures } \\
\text { the use, integration, } \\
\text { accumulation, and } \\
\text { transformation of } \\
\text { competencies related to new } \\
\text { PM practices } \\
\text { and methodologies }\end{array}$ & $\begin{array}{l}\text { 9. How do you ensure that the } \\
\text { new PM methodologies are } \\
\text { used and disseminated in the } \\
\text { projects and teams? }\end{array}$ & 9. Seizing \\
\hline & \multirow{3}{*}{$\begin{array}{l}\text { O6. Analyze if agile and } \\
\text { waterfall methodology } \\
\text { develop DCs differently }\end{array}$} & $\begin{array}{l}\text { 10. Do you consider that the } \\
\text { agile and waterfall } \\
\text { methodologies develop } \\
\text { skills differently? }\end{array}$ & 10. Reconfiguration \\
\hline & & $\begin{array}{l}\text { 11. What skills do they } \\
\text { develop and how? }\end{array}$ & 11. Reconfiguration \\
\hline & & $\begin{array}{l}\text { 12. Which one allows greater } \\
\text { development and } \\
\text { reconfiguration of } \\
\text { competencies in } \\
\text { the organization? }\end{array}$ & 12. Reconfiguration \\
\hline $\begin{array}{l}1.3 \text { How does the resource } \\
\text { turnover between projects } \\
\text { allow for the accumulation, } \\
\text { integration, utilization, and } \\
\text { reconfiguration } \\
\text { of knowledge? }\end{array}$ & $\begin{array}{l}\text { O7. Identify what factors can } \\
\text { mitigate the impact of } \\
\text { resource turnover between } \\
\text { projects on knowledge } \\
\text { transfer, capacity utilization, } \\
\text { and codification }\end{array}$ & $\begin{array}{l}\text { 13. How is it ensured that the } \\
\text { skills and knowledge } \\
\text { developed in each project stay } \\
\text { in the organization and are } \\
\text { replicated and used in other } \\
\text { projects given the nature of } \\
\text { project turnover? }\end{array}$ & 13. Accumulation \\
\hline
\end{tabular}

\section{References}

1. Jantunen, A.; Tarkiainen, A.; Chari, S.; Oghazi, P. Dynamic capabilities, operational changes, and performance outcomes in the media industry. J. Bus. Res. 2018, 89, 251-257. [CrossRef]

2. Eriksson, T. Processes, antecedents and outcomes of dynamic capabilities. Scand. J. Manag. 2014, 30, 65-82. [CrossRef]

3. Eisenhardt, K.M. Building theories from case study research. Acad. Manag. Rev. 1989, 14, 532-550. [CrossRef]

4. Patrício, V.; Lopes da Costa, R.; Pereira, L.; António, N. Dynamic Capabilities and Project Management: A systematic literature review. Int. J. Bus. Innov. Res. 2021, in press.

5. Davies, A.; Brady, T. Explicating the dynamics of project capabilities. Int. J. Proj. Manag. 2016, 34, 314-327. [CrossRef]

6. Gardiner, P.D. Creating and appropriating value from project management resource assets using an integrated systems approach. In Proceedings of the Selected Papers from the 27th IPMA World Congress, Dubrovnik, Croatia, 30 September-3 October 2013.

7. Zhang, S.; Leiringer, R. Owner Project Capabilities in infrastructure projects: Unpacking Commercial Capabilities. In Proceedings of the 32nd Annual ARCOM Conference; Chan, P.W., Neilson, C.J., Eds.; Association of Researchers in Construction Management: Manchester, UK, 2016; Volume 1, pp. 185-194.

8. Hermano, V.; Martín-Cruz, N. The role of top management involvement in firms performing projects: A dynamic capabilities approach. J. Bus. Res. 2016, 69, 3447-3458. [CrossRef]

9. Zerjav, V.; Edkins, A.; Davies, A. Project capabilities for operational outcomes in inter-organisational settings: The case of London Heathrow Terminal 2. Int. J. Proj. Manag. 2018, 36, 444-459. [CrossRef]

10. Biesenthal, C.; Gudergan, S.; Ambrosini, V. The role of ostensive and performative routine aspects in dynamic capability deployment at different organizational levels. Long Range Plann. 2019, 52, 350-365. [CrossRef]

11. Bernroider, E.W.N.; Wong, C.W.Y.; Lai, K.-H. From dynamic capabilities to ERP enabled business improvements: The mediating effect of the implementation project. Int. J. Proj. Manag. 2014, 32, 350-362. [CrossRef]

12. Yan, M.-R.; Tran-Danh, N.; Hong, L.-Y. Knowledge-based decision support system for improving e-business innovations and dynamic capability of IT project management. Knowl. Manag. Res. Pract. 2019, 17, 125-136. [CrossRef]

13. Andersson, T.; Chapman, R. Project strategy for product innovation: The strategic project management framework. Int. J. Proj. Organ. Manag. 2017, 9, 328-349. [CrossRef]

14. Daniel, E.M.; Ward, J.M.; Franken, A. A dynamic capabilities perspective of IS project portfolio management. J. Strateg. Inf. Syst. 2014, 23, 95-111. [CrossRef] 
15. Davies, A.; Dodgson, M.; Gann, D. Dynamic capabilities in complex projects: The case of London Heathrow Terminal 5. Proj. Manag. J. 2016, 47, 26-46. [CrossRef]

16. Freitas, S.L.T.U.; Salerno, M.S. Creation of dynamic capacities and their evolution through engineering projects. Rev. Bras. Gest. Neg. 2018, 20, 495-515.

17. Manley, K.; Chen, L.E. Collaborative learning model of infra-structure construction: A capability perspective. Const. Innov. 2015, 15, 355-377. [CrossRef]

18. Sicotte, H.; Drouin, N.; Delerue, H. Innovation portfolio management as a subset of dynamic capabilities: Measurement and impact on innovative performance. Proj. Manag. J. 2014, 45, 58-72. [CrossRef]

19. Thattakath, E.W.; Čiutienè, R. The relationship between dynamic capabilities and project portfolio risk management: Theoretical framework. In Proceedings of the Sixth International Scientific Conference on Project Management in the Baltic Countries, Riga, Latvia, 27-28 April 2017.

20. Patrício, V.S.; Pereira, L.F.; Santos, J.P. Dynamic Capabilities trends: A brief review of the state of the art. In Proceedings of the 2019 IEEE International Conference on Engineering, Technology and Innovation (ICE/ITMC), Valbonne Sophia-Antipolis, France, 17-19 June 2019.

21. Medina, R.; Medina, A. The competence loop: Competence management in knowledge-intensive, project-intensive organizations. Int. J. Manag. Proj. Bus. 2015, 8, 279-299. [CrossRef]

22. Eisenhardt, K.M. Agency theory: An assessment and review. Acad. Manag. Rev. 1989, 14, 57-74. [CrossRef]

23. Cesarotti, V.; Gubinelli, S.; Introna, V. The evolution of Project Management (PM): How Agile, Lean and Six Sigma are changing PM. J. Mod. Proj. Manag. 2019, 7, 1-29.

24. Teece, D.J. Explicating dynamic capabilities: The nature and microfoundations of (sustainable) enterprise performance. Strateg. Manag. J. 2007, 28, 1319-1350. [CrossRef]

25. Tereso, A.; Ribeiro, P.; Fernandes, G.; Loureiro, I.; Ferreira, M. Project Management practices in private organizations. Proj. Manag. J. 2018, 50, 1-17. [CrossRef]

26. Farashah, A.D.; Thomas, J.; Blomquist, T. Exploring the value of project management certification in selection and recruiting. Int. J. Proj. Manag. 2019, 37, 14-26. [CrossRef]

27. Project Management Institute (PMI). A Guide to the Project Management Body of Knowledge, PMBok®Guide, 6th ed.; Project Management Institute: Newtown Square, PA, USA, 2017.

28. Collyer, S.; Warren, C.; Hemsley, B.; Stevens, C. Aim, fire, aim-Project planning styles in dynamic environments. Proj. Manag. J. 2010, 41, 108-121. [CrossRef]

29. Conforto, E.C.; Amaral, D.C.; da Silva, S.L.; Di Felippo, A.; Kamikawachi, D.S.L. The agility construct on project management theory. Int. J. Proj. Manage. 2016, 34, 660-674. [CrossRef]

30. Fernandes, G.; Ward, S.; Araújo, M. Developing a framework for embedding useful project man-agement improvement initiatives in organizations. Proj. Manag. J. 2014, 45, 81-108. [CrossRef]

31. Eisenhardt, K.M.; Martin, J.A. Dynamic capabilities: What are they? Strateg. Manag. J. 2000, 21, 1105-1121. [CrossRef]

32. Gomes, J.; Romão, M. Achieving dynamic capabilities through the benefits management approach. IJISSS 2018, 10, 53-68. [CrossRef]

33. Ambrosini, V.; Bowman, C. What are dynamic capabilities and are they a useful construct in strategic management? Int. J. Manag. Rev. 2009, 11, 29-49. [CrossRef]

34. Teece, D.J.; Pisano, G.; Shuen, A. Dynamic capabilities and strategic management. Strateg. Manag. J. 1997, 18, 509-533. [CrossRef]

35. Zahra, S.A.; Sapienza, H.J.; Davidsson, P. Entrepreneurship and dynamic capabilities: A review, model and research agenda. J. Manag. Stud. 2006, 43, 917-955. [CrossRef]

36. Cardeal, N.; Antonio, N.S. Valuable, Rare, Inimitable Resources and Organization (VRIO) resources or Valuable, Rare, Inimitable Resources (VRI) capabilities: What leads to competitive advantage? Afr. J. Bus. Manag. 2012, 6, 10159-10170. [CrossRef]

37. Di Stefano, G.; Peteraf, M.; Verona, G. Dynamic capabilities deconstructed: A bibliographic investigation into the origins, development, and future directions of the research domain. Ind. Corp. Chang. 2010, 19, 1187-1204. [CrossRef]

38. Sivusuo, J.; Sivusuo, H.; Takala, J. Model of excellence: From individuals to Dynamic Capabilities. Management 2018, 13, 97-109. [CrossRef]

39. Teece, D.J. The foundations of enterprise performance: Dynamic and Ordinary Capabilities in an (economic) Theory of Firms. Acad. Manag. Perspect. 2014, 28, 328-352. [CrossRef]

40. Pandza, K.; Horsburgh, S.; Gorton, K.; Polajnar, A. A real options approach to managing resources and capabilities. Int. J. Oper. Prod. Manag. 2003, 23, 1010-1032. [CrossRef]

41. Yin, R.K. Case Study Research and Applications: Design and Methods, 6th ed.; SAGE: Los Angeles, CA, USA, 2018.

42. Saunders, M.; Lewis, P.; Thornhill, A. Research Methods for Business Students; Pearson Education: Harlow, UK, 2009.

43. Charmaz, K. Constructing Grounded Theory-A Pratical Guide Through Qualitative Analysis; SAGE: Thousand Oaks, CA, USA, 2006.

44. Bryman, A. Social Research Methods, 5th ed.; Oxford University Press: Oxford, UK, 2016.

45. Strauss, A.; Corbin, J. Grounded Theory Methodology: An Overview. In Handbook of Qualitative Research, 1st ed.; Denzin, N., Lincoln, Y., Eds.; Sage: Thousand Oaks, CA, USA, 1994; pp. 273-285.

46. Strauss, A.; Corbin, J. Pesquisa Qualitativa-Tecnicas e Procedimentos para o Desenvolvimento de Teoria Fundamentada; Artmed Editora SA: São Paulo, Brazil, 2008. 
47. Glaser, B.G.; Strauss, A.L. The Discovery of Grounded Theory-Strategies for Qualitative Research; AldineTransaction a Division of Transaction Publishers: Piscataway, NJ, USA, 1967.

48. Lincoln, Y.S.; Guba, E.G. Naturalistic Inquiry; SAGE: Beverly Hills, CA, USA, 1985.

49. Carcary, M. The research audit trial-Enhancing trustworthiness in qualitative inquiry. Electron. J. Bus. Res. Methods 2009, 7, 11-24.

50. García, H.C.; Gardó, T.F.; García, J.M.G. SMES dynamic learning capabilities in international public procurement. J. Mod. Proj. Manag. 2018, 5, 14-23.

51. Clegg, S.; Killen, C.P.; Biesenthal, C.; Sankaran, S. Practices, projects and portfolios: Current research trends and new directions. Int. J. Proj. Manag. 2018, 36, 762-772. [CrossRef]

52. Pereira, L.; Santos, R.; Sempiterno, M.; Costa, R.L.D.; Dias, Á.; António, N. Pereira Problem solving: Business research methodology to explore Open Innovation. J. Open Innov. Technol. Mark. Complex. 2021, 7, 84. [CrossRef]

53. Teece, D.J. Dynamic capabilities: Routines versus entrepreneurial action. J. Manag. Stud. 2012, 49, 1395-1401. [CrossRef]

54. Zhang, L.; Tang, Z.; Yu, F. A IPD team's dynamic capabilities and their impact on team collaboration satisfaction. In Proceedings of the 38th International Annual Conference of the American Society for Engineering Management (ASEM 2017), Reimagining Systems Engineering and Management, Huntsville, AL, USA, 18-21 October 2017.

55. Zollo, M.; Winter, S.G. Deliberate learning and the evolution of dynamic capabilities. Organ. Sci. 2002, 13, 339-351. [CrossRef]

56. Pereira, L.; Fernandes, A.; Sempiterno, M.; Dias, Á.; Lopes da Costa, R.; António, N. Knowledge management maturity contributes to project-based companies Open Innovation era. J. Open Innov. Technol. Mark. Complex. 2021, 7, 126. [CrossRef]

57. Valdez-Juárez, L.H.; Castillo-Vergara, M. Technological Capabilities, Open Innovation, and Eco-Innovation: Dynamic Capabilities to Increase Corporate Performance of SMEs. J. Open Innov. Technol. Mark. Complex. 2021, 7, 8. [CrossRef]

58. Oh, M.; Choi, S. The Competence of Project Team Members and Success Factors with Open Innovation. J. Open Innov. Technol. Mark. Complex. 2020, 6, 51. [CrossRef]

59. Rotjanakorn, A.; Sadangharn, P.; Na-Nan, K. Development of Dynamic Capabilities for Automotive Industry Performance under Disruptive Innovation. J. Open Innov. Technol. Mark. Complex. 2020, 6, 97. [CrossRef]

60. Lopes da Costa, R.; António, N.; Pereira, L.; Dias, P. Ethnography and Management Talent as a tools to knowledge sharing in the consulting sector. J. Rev. Global. Econ. 2019, 8, 183-195. [CrossRef]

61. Pereira, L.; Pinto, M.; Costa, R.L.D.; Dias, Á.; Gonçalves, R. The new SWOT for a sustainable world. J. Open Innov. Technol. Mark. Complex. 2021, 7, 18. [CrossRef]

62. Radnejad, A.B.; Osiyevskyy, O.; Vredenburg, H. Barriers to radical process innovation: A case of environmental technology in the oil industry. J. Strat. Manag. 2020, 13, 453-476. [CrossRef]

63. Radnejad, A.B.; Vredenburg, H.; Woiceshyn, J. Meta-organizing for open innovation under environmental and social pressures in the oil industry. Technovation 2017, 66, 14-27. [CrossRef] 